University of Tennessee College of Law

Legal Scholarship Repository: A Service of the Joel A. Katz Law Library

UTK Law Faculty Publications

Summer 2017

Equality and Nondiscrimination through the Eyes of an

International Religious Organization: The Organization of Islamic

Cooperation's (OIC) Response to Women's Rights

Robert Blitt

Follow this and additional works at: https://ir.law.utk.edu/utklaw_facpubs

Part of the Law Commons

Recommended Citation

Blitt, Robert, "Equality and Nondiscrimination through the Eyes of an International Religious Organization: The Organization of Islamic Cooperation's (OIC) Response to Women's Rights" (2017). UTK Law Faculty Publications. 172.

https://ir.law.utk.edu/utklaw_facpubs/172

This Article is brought to you for free and open access by Legal Scholarship Repository: A Service of the Joel A. Katz Law Library. It has been accepted for inclusion in UTK Law Faculty Publications by an authorized administrator of Legal Scholarship Repository: A Service of the Joel A. Katz Law Library. For more information, please contact eliza.boles@utk.edu. 


\section{TS THE UNVERSTYY OF TENAESSEE KNOXVILLE}

COLLEGE OF LAW
Legal Studies

Research Paper Series

Research Paper \#326

September 2017

\title{
Equality and Nondiscrimination Through the Eyes of an International Religious Organization: The Organization of Islamic Cooperation's (OIC) Response to Women's Rights
}

\author{
Robert C. Blitt \\ Wisconsin International Law J ournal, Vol. 34, No. 4 (2017) \\ This paper may be downloaded without charge \\ from the Social Science Research Network Electronic library at: \\ http://ssrn.com/abstract=2978646
}

Learn more about the University of Tennessee College of Law: law.utk.edu 


\title{
EQUALITY AND NONDISCRIMINATION THROUGH THE EYES OF AN INTERNATIONAL RELIGIOUS ORGANIZATION: THE ORGANIZATION OF ISLAMIC COOPERATION'S (OIC) RESPONSE TO WOMEN'S RIGHTS
}

\author{
ROBERT C. BLITT ${ }^{*}$
}

\begin{abstract}
This article is the first of a two part series that draws on women's rights and sexual orientation and gender identity (SOGI) to explore how the Organization of Islamic Cooperation (OIC) represents, interprets and seeks to impact the right to equality and protection against discrimination as enshrined under international human rights law. The study is a novel one inasmuch as the OIC is neither a state nor a religious group per se. Rather, the OIC stands out as the only contemporary intergovernmental organization unifying its member states around the commonality of a single religion. In this capacity, the organization maintains no direct obligations or rights under key instruments such as the Universal Declaration on Human Rights (UDHR) or the International Covenant on Civil and Political Rights (ICCPR).

Nevertheless, as part of its mandate representing 57 predominantly Muslim states, the OIC has increasingly asserted a role for itself on the international stage as "the collective voice of the Muslim world." This new assertiveness is particularly evident in the context of debates surrounding the content of human rights norms in international fora such as the United Nations, where the OIC has sought to develop common policy positions and encourage its members to vote as a bloc on issues of concern. Against this backdrop, the article concludes that supporters of universal human rights norms need to better understand how the OIC's mission to "protect and defend the true image of Islam" may impact international debates over the substance of equality and
\end{abstract}

Professor of Law, University of Tennessee College of Law. The author extends thanks to the organizers of the 2015 International Conference on Religion and Equality, held at the Bar Ilan University and to the conference participants who provided feedback on an early version of this article. 
nondiscrimination norms, and develop appropriate responses to these efforts as a means to ensure that universality is not undermined.

This article begins with a brief introduction to the OIC, and proceeds to explore its relationship with the principles of equality and nondiscrimination by examining its founding document and other relevant primary sources. With this understanding in place, the paper turns to examine the OIC's contemporary handling of these principles as manifested in debates surrounding women's rights as well as the relevance and impact of "Islamic family values" on the scope of those rights. This article's exploration of "family values" also serves as a pivot point to begin framing rights issues related to Lesbian, Gay, Bisexual, Transgender, and Intersex (LGBTI) individuals and related SOGI issues. Throughout this examination, the role of the OIC's newly established Independent Permanent Human Rights Commission (IPHRC) is considered as a means of appraising whether a shift in the OIC's position may be forthcoming.

Abstract 755

Introduction

I. The Blunder Years: The OIC's Early Take on Equality and

Nondiscrimination

A. 1972 Charter of the Organization of the Islamic Conference 761

B. OIC Cairo Declaration on Human Rights in Islam 762

II. Laying the Foundation for Human Rights "Mainstreaming" at the

OIC: New Policies and Institutions

A. A Ten Year Program of Action and Much Ado About Islamic Human Rights Covenants 769

B. Old Wine, New Bottle? A New Organizational Charter and a Rebranded OIC

C. The OIC's "Independent" Permanent Human Rights

Commission

1. IPHRC Mandate Anchored to CDHRI Relativism

2. Branding Effort Aside, IPHRC Statute Ensures

Commission Will Be Anything but Independent (or

Pluralist)

III. Plan into Action: Recent Manifestations of the OIC's Vision for

Equality and Nondiscrimination

A. Women's Rights. 
1. OIC Plan of Action for the Advancement of Women

(OPAAW)

2. OIC Organization of Women Development (WDO) ...... 798

3. IPHRC on Women's Equality........................................... 800

4. Different "Roles and Responsibilities": A Frontal

Challenge to Women's Equality

5. Shari'ah and Women's Equality

B. Protection of Family Values: Nexus for Discrimination

Against Women, on the Basis of Sexual Orientation and

Gender Identity, and Against Others

1. Sexual and Reproductive Health.

2. Protecting an "Ideal Family" Demands Religious

Conformity, Not Recognition of Family Diversity

IV. Conclusion

\section{INTRODUCTION}

Comprised of fifty-seven predominantly Muslim member states, the Organization of Islamic Cooperation (OIC) describes itself as the "second largest inter-governmental organization after the United Nations" and "the collective voice of the Muslim world," whose raison d'être is to "safeguard and protect the interests of the Muslim world." In asserting this mandate, the OIC also embodies the only contemporary intergovernmental organization that claims to unify its member states around the common banner of a single religion. ${ }^{2}$

At the United Nations (UN), the OIC maintains official observer status and represents nearly a third of all UN member states. ${ }^{3}$

1 ORganisation OF ISLAMIC COOPERATION, History, http://www.oicoci.org/page/?p_id=52\&p_ref=26\&lan=en.

2 Abdel Monem Al-Mashat, The Organization of the Islamic Conference and the Post Cold War Era, in THE ORganization of the IsLamic CONFERENCE IN A CHANGing World 147, 150 (Mohammad El Sayed Selim ed., 1994). Ioana Cismas describes the OIC as "the sole intergovernmental actor to display religious contours and to claim the role of interpreter of human rights in the context of Islam" and an organization where "the role of religion is intertwined with political goals." IOANA CiSMAS, RELIGIOUS ACTORS AND INTERNATIONAL LAW 239, 241 (2014).

3 The OIC has maintained observer status at the UN since 1975. The UN General Assembly also regularly adopts by consensus resolutions on "Cooperation between the United Nations and the Organization of Islamic Cooperation.” See G.A. Res. 3369 (Oct. 10, 1975); see also G.A. Res. 67/264 (May 15, 2013). 
Nevertheless, since adoption of its original Charter in $1972,{ }^{4}$ the OIC generally has had limited success placing communal interests above the realpolitik interests of its individual member states. ${ }^{5}$ This reality stems in part from the fact that the organization's members - despite sharing the commonality of a religion broadly framed ${ }^{6}$ - harbor a sweeping diversity of cultures, legal traditions, and development levels, as well as longstanding political and religious rivalries. ${ }^{7}$ From this admixture, wealthy and traditionally conservative states-with Saudi Arabia as the vanguard - emerged with primary control over the organizational reins of power and influence. ${ }^{8}$ By the late 1990 s, a former OIC assistant secretary general described the resulting institutional product as:

a conglomeration of staggering disparities in terms of size, population, wealth, human development, state of political evolution, and political systems. The regional issues and local conflicts, domestic tensions and vulnerability to external interference have

4 Organization of the Islamic Conference, Charter of the Organization of the Islamic Conference, Mar. 4, 1972.

5 According to one blunt critique leveled by a former Pakistani diplomat in the mid-1990s: "Suffice it to say that the OIC is in a coma. There are internal causes and external circumstances for it." S.M. Koreshi, Security and Development Interests of OIC Countries in Post Gulf War Era, in OIC: CONTEMPORARY ISSUES OF THE MusLIM WORLD 141, 145 (Ghulam Sarwar, ed., 1997); a more nuanced assessment offers that "The overall picture which emerges . . . of the performance of the OIC ... is that we are dealing with an organization which had made significant advances in the areas of technical co-operation ... but had achieved very little in the areas of collective security and the peaceful resolution of disputes." Mohammad El Sayed Selim, An Evaluation of the Performance of the Organization of the Islamic Conference, in THE ORGANIZATION OF THE ISLAMIC CONFERENCE IN A CHANGING WORLD 136 (2011).

6 Nine states retain OIC membership despite the absence of a majority Muslim population. The revised 2008 OIC Charter now requires as a condition of membership that any state seeking to join the OIC have a Muslim majority. OIC, Charter of the Organization of the Islamic Conference, Mar. 14, 2008, at art. 3(2).

7 The divisions among OIC member states are as stark as they are numerous. Consider just a few: on resources, oil-rich and oil-poor; on constitutions, declared secular and declared Islamic; on relationships with the United States, friend and foe; on population diversity, virtually 100 percent Muslim and below 50 percent Muslim; and on Islamic denomination, Sunni and Shi'a. Early opposition to the OIC from secular Muslim states stressed that the rationale underpinning the OIC - the use of Islam as a unifying political tool-went "against the spirit of modern nations." Abdullahil Ahsan, Muslim Society in Crisis: A Case Study of the Organization of the Islamic Conference 51 (1985) (unpublished PhD dissertation, History, University of Michigan). In 1994, Al Mashat concluded, "National interests over shadow the doctrines and the ideological basis of the OIC." Al Mashat, supra note 2, at 151.

8 One observer attributes this dynamic to four factors: Saudi King Faisal drove the original initiative for the OIC; its headquarters is situated in Jeddah; the Saudi government contributed "around 10 percent of the OIC budget, and most of the high-ranking as well as middle ranking officials"; and finally, the Saudis secured support from other conservative states as well as those on the receiving end of Saudi financial assistance. Sohrab Shahabi, OIC and Its Prospects for the Future, in OIC: CONTEMPORARY ISSUES OF THE MUSLIM WORLD, supra note 5, at 173-74.. 
further weakened the collective resolve. . .were it not already there, it would be impossible to invent an OIC under the prevailing situation amounting to chaos. Therefore, the OIC, despite its manifold weaknesses, must be preserved. ${ }^{9}$

More recently, however, the OIC has attempted to reinvigorate its international relevance. This effort is reflected in the OIC's 2005 Tenyear Programme of Action to Meet the Challenges Facing the Muslim $U_{m m a h}{ }^{10}$ and in its revised 2008 Charter. ${ }^{11}$ Some observers also attribute the organization's pivot away from a restrictive-and ineffectiveposture to the leadership Ekmeleddin Ihsanoglu, the OIC's Secretary General from 2004 to $2014 .^{12}$ The outcome of these developments has engendered a conscious effort to systematize and deepen the nature of OIC engagement on the international level, particularly as it relates to international human rights. Although the OIC has affirmed the UN vision of universal human rights norms, it simultaneously advocates within the UN system to promote its own Islamic worldview and continues to endorse a parallel system of treaties that would govern its member states' conduct on the basis of Islamic norms. ${ }^{13}$ This approach is evident in the organization's continued drive to enforce bloc voting among its members

9 Refaqat Syed, Organisation of the Islamic Conference: Dream and Reality, in OIC: CONTEMPORARY ISSUES OF THE MUSLIM WORLD, supra note 5 at 221.

10 Ten-year programme of action to meet the challenges facing the Muslim Ummah in the 21st century, Third Extraordinary Session of the Islamic Summit Conference (2005); perhaps the biggest paradox here is that while the OIC invokes the foundational Islamic principle of ummah - a "brotherhood more vital than that of blood" or a bond to transcend all other bondsits Charter is premised on the modern nation state and holds as sacrosanct the secular legal principle of state sovereignty; See Katja L.H. Samuel, THE OIC, THE UN, AND CounTERTERRORISM LAW-MAKING: CONFLICTING OR COOPERATIVE LEGAL ORDERS? 30 (2013) (citing John A. Williams, THEMES OF IsLAMIC CiviLIZATION (1971)); see also Ahsan, supra note 7, at 65; see also Alpaslan Özerdem, The Contribution of the Organization of the Islamic Conference to the Peace Process in Mindanao, in External InTERVEnTIONS In Civil Wars: THe Role AND IMPACT OF REGIONAL AND INTERNATIONAL ORGANISATIONS 97, 98 (Stefan Wolff and Oya Dursun-Özkanca eds., 2014) (arguing that upholding the premise of nation states represents a serious disruption in the connection between individual Muslims and the ummah, which is intended to be a single collectivity that rejects nation state sovereignty).

11 See 2008 OIC Charter, supra note 6.

12 Melinda Negrón-Gonzales, Organization of Islamic Cooperation (OIC), in INTERNATIONAL ORGANIZATIONS AND THE IMPLEMENTATION OF THE RESPONSIBILITY TO PROTECT: THE HUMANITARIAN CRISIS IN SYRIA 90, 90-91 (Daniel Silander and Don Wallace eds., 2015) (describing Ihsanoglu as "reformist" and - in his own words - as promoting "modernization and moderation"). This shift may have been short-lived given that, since January 2014, the OIC Secretariat is led by a Saudi secretary general.

13 Katja Samuel, Universality, the UN and the Organization of the Islamic Conference: Single, Complementary or Competing Universal Legal Orders?, in INTERNATIONAL LAW IN A MulTiPOLAR WORLD 263, 275 (Matthew Happold ed., 2012). 
at the United Nations, ${ }^{14}$ as well as in the development of an OIC treaty framework to regulate human rights, including the rights of children and women, on the basis of unspecified Islamic norms. ${ }^{15}$

Throughout this revitalized engagement, the OIC has assumed a unique role. The OIC is neither a state nor a centralized religious organization authorized to represent the Muslim faith or authoritatively interpret or enforce Islamic law. Yet, its initiatives suggest a desire to vitiate existing international human rights norms by subjecting them to a parochial "poison pill" based on the OIC's conception of Islamic human rights. As this article argues, the failure to decisively reject the OIC's efforts to promulgate a religiously-justified and restrictive framing of equality and nondiscrimination risks undermining the spirit of universality reflected in the Universal Declaration of Human Rights (UDHR) grundnorm that "all human beings are born free and equal in dignity and rights," 16 and more immediately, legitimizes ongoing rights violations against women as well as lesbian, gay, bisexual, transgender, and intersex (LGBTI) persons, among others.

To better understand the OIC's vision for equality and nondiscrimination and its potential impact on international norms, this article begins by examining how the organization's foundational and other early primary documents relate to the principles of equality and nondiscrimination. The article then explores the OIC's more recent attempts to mainstream human rights and weighs the extent to which treatment of equality and nondiscrimination has evolved or been elaborated by the institution, including through the establishment of a

14 Organization of Islamic Cooperation [OIC], Final Communique of the Annual Coordination Meeting of the Ministers of Foreign Affairs of the OIC Member States, II 122 (Sept. 27, 2013) ("The Meeting urged Member States to implement Resolution No. 41/37-POL on coordination and voting patterns of Member States at the United Nations and other international and multilateral fora."); more recently, the OIC has "insisted that failure to vote for [OIC-backed resolutions at the $\mathrm{UN}]$ and announcement of positions different from those agreed on is contrary to the unanimity imposed by the duty of Islamic solidarity among Member States." OIC Doc. OIC/13TH SUMMIT 2016/FC/FINAL, II 199 (Apr. 14-15, 2016).

15 To date, this framework includes a Covenant on the Rights of the Child in Islam, and plans for an Islamic Charter on Human Rights, a Covenant on the Rights of the Women in Islam, an Islamic Covenant against Racial Discrimination, as well as an International Islamic Court of Justice intended to function as a principal OIC organ. At the time of writing, each of these is at a different stage of development, though none have reached the point of entering into force. Robert C. Blitt, The Bottom Up Journey of "Defamation of Religion" from Muslim States to the United Nations: A Case Study of the Migration of Anti-Constitutional Ideas, in STUDIES IN LAW, POLITICS, AND SOCIETY 121, 172-173 (2011).

16 G.A. Res. 217 (III) A, Universal Declaration of Human Rights (Dec. 10, 1948), at art. 1 [hereinafter UDHR]. 
new Independent Permanent Human Rights Commission (IPHRC). With this baseline established, the remainder of the article focuses on the OIC's approach to women's rights to help understand how the organization's positions directly impact the scope and interpretation of equality and nondiscrimination. In addition to considering the OIC's own policies aimed at addressing disparities impacting women and its posture vis á vis international treaty bodies, this section will also unpack the OIC's campaign to promote "protection of the family", inasmuch as this effort exposes women to further risk of inequality and discrimination, and also serves as a pivot point to begin framing the OIC's approach to LGBTI rights and related SOGI issues. The article concludes by considering the OIC's position moving forward and by offering recommendations for ensuring respect for the universal right to equality and nondiscrimination.

\section{THE BLUNDER YEARS: THE OIC'S EARLY TAKE ON EQUALITY AND NONDISCRIMINATION}

\section{A. 1972 CHARTER OF THE ORGANIZATION OF THE ISLAMIC CONFERENCE}

The only reference to equality contained in the OIC's 1972 Charter relates to equality between member states of the organization. ${ }^{17}$ The Charter makes no reference to family, women, Islamophobia, ${ }^{18}$ defamation of religion, or Shari'ah. ${ }^{19}$ At the same time, the preamble reaffirms the "commitment to the UN Charter and fundamental Human Rights" and acknowledges the principle of nondiscrimination. ${ }^{20}$ The preamble also expresses resolve "to preserve Islamic spiritual, ethical, social and economic values," ${ }^{21}$ while it omits any explicit references

171972 OIC CHARTER, supra note 4, at art. II(B)(1).

18 Omission of "Islamophobia" is not surprising inasmuch as the term was not coined until the early 1990s. See University of California, Berkeley Center for Race and Gender Islamophobia Research \& Documentation Project, Defining "Islamophobia", http://crg.berkeley.edu/content/islamophobia/defining-islamophobia ("The term 'Islamophobia' was first introduced as a concept in a 1991 Runnymede Trust Report and defined as 'unfounded hostility towards Muslims, and therefore fear or dislike of all or most Muslims.' The term was coined in the context of Muslims in the UK in particular and Europe in general, and formulated based on the more common 'xenophobia' framework").

191972 OIC CHARTER, supra note 4, at art. II(B)(1).

20 Id. at preamble.

21 Id. 
either to Shari'ah or Islamic legal norms. Specific organizational objectives contained in the OIC's 1972 Charter include: promoting Islamic solidarity; eliminating racial discrimination, segregation, and colonialism; and supporting all Muslims "with a view to preserving their dignity, independence and national rights." 22 This document's limited aspirations - and its primary invocation of Palestine as a rallying call for all Muslim states ${ }^{23}$ - betrays the significant divisions that colored the Muslim world at the time, as well as the states' preoccupation with their own national priorities. ${ }^{24}$

\section{B. OIC CAIRO DECLARATION ON HUMAN RIGHTS IN ISLAM}

Twenty years later, the OIC promulgated its Cairo Declaration on Human Rights in Islam (CDHRI) ${ }^{25}$ This document emerged from a long and convoluted internal drafting process that spanned nearly a

22 Id. at art. II(A)(1), (3) and (6).

${ }^{23}$ Id. at art. II(A)(5) and $\mathrm{V}(2)(\mathrm{e})(\mathrm{ii})$ (establishing as an OIC objective supporting the "struggle of the people of Palestine, to help them regain their rights and liberate their land"); see also ARshad-UZ Zaman, Privileged Witness: Memoirs of A DiPlomat 218-219 (2000) (observing "of all the activities of the OIC, Palestine held the most important place. ... Although there were many political issues that the OIC was grappling with, Palestine and Jerusalem remained on the top of the agenda"); see also Syed, supra note 9, at 217 (concluding the "OIC became not a vehicle but a captive of [the Palestine] issue. ... Having developed a very strong position within the Secretariat, and playing upon the emotional content of the issue, [the Palestine Liberation Organization] would not permit other issues to be brought at par with the issues related to Palestine."); see also Ahsan, supra note 7, at 99 (concluding "[t]he OIC has only succeeded in mobilizing all its members on the issue of Palestine. In spite of this complete mobilization, the OIC has failed to achieve its goals even on that issue. ... OIC countries had stronger commitments to nation-state identity than to the Ummah identity"). As a concrete manifestation of this reality, consider for example that one-third of the political resolutions from the 1990 Islamic Conference of Foreign Ministers were dedicated to the Israeli-Palestinian conflict. See Organization of Islamic Cooperation [OIC], Report and Resolutions on Political, Legal and Information Affairs (Jul. 31-Aug. 5, 1990), http://www.oicoci.org/english/conf/fm/19/19\%20icfm-political-en.htm.

24 According to former OIC Secretary General Ihsanoglu, the 1972 OIC Charter "did not get more than 23 signatures over its 40 years of existence." Secretary General Prof. Ekmeleddin Ihsanoglu, Address of OIC Secretary General to the Senior Officials Preparatory Meeting for the 37th Session of the Council of Foreign Ministers (Apr. 12-14, 2010) OIC Doc. OIC/SOM/37CFM/2010/SG.SP, 11. In contrast, the 2008 OIC Charter secured 39 signatures and 14 ratifications within two years. 2008 OIC Charter, supra note 6.

25 The document emerged from an internal drafting process that can be traced back to at least 1984 . See Final Communique, Fifteenth Islamic Conference of Foreign Ministers, Dec. 18-22, 1984, If E ("The Conference decided to entrust the General Secretariat with the task of" requesting member states to designate their respective experts for a meeting of a legal committee to examine anew the draft declaration of human rights in Islam in terms of content); see also Sixteenth Islamic Conference of Foreign Ministers, Jan. 6-10, 1986, Resolution No. 2/16-ORG Human Rights In Islam. 
decade. In 1981, the Third Islamic Summit Conference's Mecca Declaration approved a decision to bring a draft document on human rights in Islam before a committee of member state representatives for the purpose of studying its content. ${ }^{26}$ Two years later, the OIC Conference of Foreign Ministers (CFM) approved the draft instrument under the title "Dhaka Declaration of Human Rights in Islam." 27 Yet, shortly after the CFM meeting, the OIC heads of state abruptly decided to validate only part of the declaration and to postpone its decision on endorsement of the entire draft until further study could be completed. ${ }^{28}$

Reviewing the substance of the Dhaka Declaration may help shed some light on why it was walked back. More religious exaltation than human rights text, the document states, among other things, that it:

\begin{abstract}
Proceed[s] from the faith of absolute oneness of God which is the basis of Islam and which calls UPON all mankind to worship no one but Allah; believe[s] in fulfilling the injunctions of the unchanging Islamic SHARIAH which calls for the safeguarding of man's religion, soul, mind, honour, wealth and progeny, and which is universal in its applicability and is characterised by moderation in all its principles and rulings, which combines spirit with matter, and which balances individual rights and obligations and collective privileges ...; affirm[s] his freedom and right to a dignified life in accordance with the Islamic Shariah; believe[s] that all human beings from [sic] one family whose members are united by their subordination to Allah ... [and believes] no one has superiority over another except on the basis of piety. ${ }^{29}$
\end{abstract}

With at least part of the Dhaka Declaration in the trash bin of history, the CFM tasked the OIC General Secretariat with identifying experts from member states to reexamine the draft declaration of human rights in Islam and make changes to "content and phraseology, in the light of the observations made by member states. ${ }^{30}$ Four years later, in 1988, a revised final text emerged and in turn was referred to the member states' ministers of justice for study and finalization. ${ }^{31}$

26 Third Islamic Summit Conference, Mecca Declaration, Jan. 25-28, 1981.

27 Fourteenth Islamic Conference of Foreign Ministers, Final Declaration, Dec. 6-11, 1983, at II 24.

28 Fourth Islamic Summit Conference, Final Communique, Jan. 16-19, 1984, at II 28.

29 Fourteenth Islamic Conference of Foreign Ministers, The Dhaka Declaration on Human Rights in Islam, Dec. 6- 11, 1983. For a more detailed treatment of the Dhaka Declaration, see Jan Hjarpe, The Contemporary Debate in the Muslim World on the Definition of "Human Rights", in ISLAM: STATE AND SocIETY 26, 34-37 (Klaus Ferdinand \& Mehdi Mozaffari eds., 1988).

30 Sixteenth Islamic Conference of Foreign Ministers, supra note 25.

31 The Seventeenth Islamic Conference of Foreign Ministers, Resolution No. 44/17-P On the Draft Document On Human Rights In Islam, Mar. 21-25, 1988. 
The revised and final Cairo Declaration, approved in 1990, represents the first authorized and concerted effort to express the OIC's position on human rights. ${ }^{32}$ Although the CDHRI is not a treaty, and therefore is not a legally binding document, the OIC's express intention was that the document, "serve as a guide for Member States in all aspects of life." ${ }^{33}$ And while the CDHRI text certainly overhauled some of the Dhaka Declaration's religious fervor, its provisions still signaled a sharp break from norms enshrined in the UDHR and its sister covenants on Civil and Political Rights (ICCPR $)^{34}$ and Economic, Social, and Cultural Rights (ICESCR). ${ }^{35}$

For example, under the CDHRI, religion represents a legitimate basis for discrimination and restricting the right to marriage ${ }^{36}$ women's equality is limited to "human dignity," and men and women retain gender-specific rights and responsibilities. ${ }^{37}$ Furthermore, freedom of movement is a right assigned only to men and is restricted based on "the framework of Shari'ah." ${ }^{38}$ Likewise, freedom of opinion, expression, and access to information are all restricted on the basis of Shari'ah. ${ }^{39}$ Beyond these specific, religion-informed limitations, the CDHRI contains two overarching provisions that make all rights contingent upon undefined religious law and further require that any definition of rights occur in an Islamic vacuum detached from international human rights instruments. The provisions state:

Art. 24: All the rights and freedoms stipulated in this Declaration are subject to the Islamic Shari'ah.

32 Organization of Islamic Cooperation, Cairo Declaration on Human Rights in Islam, Aug. 5, 1990, Annex to Res. No. 49/19-P [hereinafter CDHRI].

$3319^{\text {th }}$ Islamic Conference of Foreign Ministers, Resolution No. 49/19-P On the Cairo Declaration on Human Rights in Islam (Session of Peace, Interdependence and Development), Jul. 31-Aug. $5,1990$.

34 See G.A. Res. 2200A (XXI), International Covenant on Civil and Political Rights (Mar. 23, 1976) [hereinafter ICCPR].

35 G.A. Res. 2200A (XXI), International Covenant on Economic, Social and Cultural Rights (Dec. 16, 1966).

${ }^{36}$ CDHRI, supra note 32, at art. 5 ("Men and women have the right to marriage, and no restrictions stemming from race, colour or nationality shall prevent them from enjoying this right."); see also Contribution of the Organisation of the Islamic Conference, UN DOC. A/CONF.157/PC/62/Add.18, (June 9, 1993).

37 CDHRI, supra note 32, at art. 6.

38 Id. at art. 12.

39 Id. at art. 22. 
Art. 25: The Islamic Shari'ah is the only source of reference for the explanation or clarification of any of the articles of this Declaration. ${ }^{40}$

Despite the CDHRI's stark departure from a universal approach to human rights, the OIC publicized the declaration as the organization's "contribution" ${ }^{41}$ to the landmark 1993 UN World Conference on Human Rights, ${ }^{42}$ delivering it to the Conference's secretary general together with

40 Id. at arts. 24, 25.

41 Twenty-First Islamic Conference of Foreign Ministers, Resolution No. 41/21-P On Coordination Among Member States in the Field of Human Rights, Apr. 25-29, 1993, art. 19. (Session of Islamic Unity and Cooperation for Peace, Justice and Progress).

42 World Conference on Human Rights, June 14-25, 1993, Vienna, Austria, OFFICE OF THE UNITED NATIONS HIGH COMMISSIONER FOR HUMAN RIGHTS, http://www.ohchr.org/EN/AboutUs/Pages/ViennaWC.aspx (last visited Mar. 5, 2017). The UN subsequently included the CDHRI-alongside regional instruments from the Organization of American States, the Council of Europe, the Organization of African Unity, and the Conference for Security and Co-operation in Europe-in a handbook compiling various international human rights instruments. U.N. OfFICE High COMM'R Human Rights, Human Rights: A COMPILATION OF INTERNATIONAL INSTRUMENTS, U.N. Doc. UN-ST/HR/1/Rev. 5 (Vol. II), U.N. Sales No. E.97.XIV.1 (1997). At least one NGO expressed "deep concern" over the decision to include the CDHRI as a "regional instrument" in a UN publication. In a written statement to the UN Commission on Human Rights from 1999, the Association for World Education (AWE) noting it was still "awaiting an explanation as to when, why, and by whom such an important decision was officially made"-reasoned the OIC was not a "regional" body and the CDHRI could not "correctly be defined as a "regional instrument." Moreover, based on CDHRI arts. 24 and 25, AWE argued the declaration's authors made "very clear that Sharia law has supremacy, and CDHRI has primacy. . over other international instruments." AWE's statement proposed deleting the CDHRI from any future reprinting, or alternatively, that the "Office of the High Commissioner should provide an explanation and a legal justification for the retention of an essentially religious document in a volume purporting to contain regional and international United Nations instruments on human rights." Comm'n on Human Rights, Letter dated Dec. 20, 1999 The Association for World Education to UN Commission on Human Rights, UN Doc. E/CN.4/2000/NGO/3 (Jan. 20, 2000) (statement title: "The 1990 'Cairo Declaration of Human Rights in Islam' (CDHRI) is neither a 'regional' instrument nor a United Nations 'international instrument"'). Without apparent explanation, the Office of the UN High Commissioner for Human Rights dropped the Cairo Declaration from the subsequent edition of its handbook, published in 2002. U.N. OfFICE High COMM'R Human Rights, Human Rights: A COMPILATION OF INTERNATIONAL INSTRUMENTS, U.N. Doc. ST/HR/1/Rev.6 (Vol. II) (2002). Despite this correction, the CDHRI (together with other OIC instruments, including the Covenant on the Rights of the Child in Islam) remains included in another UN publication, THE Right TO HUMAN RIGHTS EDUCATION: A COMPILATION OF PROVISIONS OF INTERNATIONAL and Regional INSTRUMENTS DEALing With Human Rights EdUCATION, most recently published in 2014. Of note, this publication appears to downgrade the status of the OIC's contribution from "regional instrument" to "other instrument" (placing it alongside Francophonie and Commonwealth documents), but indicates no concern for the fact that the OIC's standards may conflict with applicable international and regional norms. The Right to Human Rights Education: A Compilation of Provisions of International and Regional Instruments Dealing with Human Rights Education, OFFICE OF THE UNITED NATIONS HIGH COMMISSIONER FOR HUMAN 
a resolution reaffirming the OIC's "strong commitment" 43 to the promotion and protection of the rights of women in accordance with CDHRI article $6 .{ }^{44}$

Professor Ioana Cismas has remarked that CDHRI article 24 "engenders a mala fide bias against OIC states, which in most cases is undeserved." ${ }^{45}$ Although it is accurate to observe that only some OIC member states boast constitutional repugnancy clauses that station Shari'ah at the apex of the legal regime, explaining away the CDHRI's incorporation of such a provision as a perceived effort to placate conservative OIC member states distorts the overall tone and substance of the declaration. ${ }^{46} \mathrm{~A}$ plain reading of the CDHRI reveals that it does not merely mollify but rather is dominated by a conservative element averse to universal human rights. ${ }^{47}$ Further, the inclusion of article 25, which makes Shari'ah the only permissible reference source for explaining or clarifying the rights contained in the document, ${ }^{48}$ should dispel any impression that the CDHRI signals a meaningful compromise between moderate and conservative forces within the OIC. By subjecting individual rights protections to the vagaries of indeterminate religious law, articles 24 and 25 untether the CDHRI from any internationally recognized human rights norms or practices ${ }^{49}$ Cismas offers that article 25 is "unfortunate ... because it does not represent the view of the majority of Muslim states." ${ }^{50}$ Yet, this timid conclusion belies the simple fact that the document offers no indication it accommodates an alternative silent majority of OIC states that presumably would have

RIGHTS

(Sep.

2014), http://www.ohchr.org/EN/Issues/Education/Training/Compilation/Pages/Listofcontents.aspx\#OI C.

43 Twenty-First Islamic Conference of Foreign Ministers, supra note 41, at art. 15.

44 CDHRI article 6 provides: "(a) Woman is equal to man in human dignity, and has rights to enjoy as well as duties to perform; she has her own civil entity and financial independence, and the right to retain her name and lineage. (b) The husband is responsible for the support and welfare of the family." CDHRI, supra note 32, at art. 6.

45 CismAS, supra note 2, at 275.

46 For example, article 3 of Afghanistan's constitution provides "no law can be contrary to the sacred religion of Islam and the values of this Constitution." Elsewhere, however, Islamic principles may be constitutionally recognized, but neither self-executing nor judicially enforceable. See Tad Stahnke \& Robert C. Blitt, The Religion-State Relationship and the Right to Freedom of Religion or Belief: A Comparative Textual Analysis of the Constitutions of Predominantly Muslim Countries, 36 GEO. J. INT'L L. 947, 951 (2005).

47 See CDHRI, supra note 32.

48 Id. at art. 25.

49 Id. at arts. 24-25.

50 CISMAS, supra note 2, at 276. 
sought to situate the CDHRI more squarely in the camp of universal rights.

In contrast, Yakin Ertürk, a former UN Special Rapporteur on violence against women, offers a more critical indictment of the Cairo Declaration. Ertürk observes that the CDHRI represents "a dominant, discriminatory paradigm [that] is presented as the only legitimate interpretation, whereas the diverse voices existing within each culture are silenced, particularly if they are those of women or other already marginalized groups." ${ }^{51}$ According to Ertürk, the CDHRI is deliberately ambiguous in its provision of women's equality and manipulates rights terminology to contest women's rights, "including the primacy [of the] right to a life free from gender-based violence." ${ }^{, 52}$ Based on these findings, Ertürk concludes that the Cairo Declaration, as a regional normative framework, is "incoherent with the universal framework that has legal precedence over [it]," 53 and "pretends that there is one homogeneous Muslim view of Islamic values," ${ }^{54}$ despite competing interpretations raised "by many others including local human rights activists living in Islamic countries or in exile, reformist clerics and selfproclaimed Islamic feminists and women's rights activists." 55

A religious perspective that contrasts with Ertürk's is useful for understanding the scope of the tension between localized and universal rights frameworks.

\begin{abstract}
We know that the primary obligation of a Muslim is to submit himself to the will of Allah Almighty. When a person chooses to embrace Islam, he necessarily submits to the Quranic value system. The [UDHR], on the other hand, advocates absolute freedom of behavior [sic]. Now, one fails to understand, how the two value systems, which are diametrically opposed to each other in their
\end{abstract}

51 U.N. Human Rights Council, UN Human Rights Council: Report of the Special Rapporteur on Violence against Women, Its Causes and Consequences on Intersections between Culture and Violence against Women, If 60, Jan. 17, 2007, A/HRC/4/34, http://www.refworld.org/docid/461e2c602.html.

52 Id. at $\mathrm{II} 40$.

$53 \quad I d$. at $\mathbb{\Phi} 41$

54 Id. at II 60; This author was able to locate only one OIC response to Ertürk's report, which suggested it would have been more appropriate for the special rapporteur to focus on impunity as an important source of violence against women rather than dominant cultural paradigms. U.N. Human Rights Council, Compte Rendu Analytique de la 15e Séance Tenue au Palais des Nations, Genëve, Mar. 20, 2007, UN Doc. A/HRC/4/SR.15, II 32 (Pakistan on behalf of the OIC: "l'OCI considère qu'il aurait été plus approprieé de mentionner, comme cause importante de violence contre les femmes, la culture de l'impunité plutôt que les paradigmes culturels dominants.").

55 U.N. Human Rights Council, supra note 51, at II 60. 
approach, would reconcile. No Muslim would forego Quranic values for the sake of Western concept of freedom of conscience or for the sake of European secular values. ... Obviously, Muslim countries cannot allow ... [any] abhorable [sic] practice [such as sexual relationships outside of marriage] [that] runs counter to Quranic values. $^{56}$

As noted above, the CDHRI does not generate legal obligations or means for its enforcement. This has not, however, precluded the OIC from using the declaration as an ongoing touchstone and rallying point for engagement on human rights issues. Still, other observers argue that the Cairo Declaration is a failed document because of "its demonstrated lack of influence on OIC members." ${ }^{\prime 7}$ The following analysis indicates that even if individual member states have grown publicly embarrassed or aloof over the CDHRI, the OIC acting on the international level as the "collective voice of the Muslim world" remains committed to the declaration. The OIC, furthermore, continues to invoke it not merely as a "contribution" to the international community, but as the institution's foundational benchmark for engaging with and limiting the impact of international human rights norms ${ }^{58}$ In the recent words of OIC Secretary General Iyad Ameen Madani, "The Cairo Declaration on Human Rights in Islam embodies the OIC's most complete statement on human rights in Islam as seen by the Member States." 59

56 Ghulam Sarwar, Introduction, in OIC: CONTEMPORARY ISSSUES OF THE MUSLIM WORLD, supra note 5 , at 15 . The UDHR does not, as the writer erroneously asserts, advocate "absolute freedom of behavior." Rather it applies a general limitation clause to all rights: "In the exercise of his rights and freedoms, everyone shall be subject only to such limitations as are determined by law solely for the purpose of securing due recognition and respect for the rights and freedoms of others and of meeting the just requirements of morality, public order and the general welfare in a democratic society." UDHR, supra note 16, at art. 29(2).

57 To support this conclusion, Cismas considers, among other things, the extent to which OIC member states invoke the CDHRI in their reporting to the UN. CISMAS, supra note 2, at 304.

58 For example, the CDHRI is prominently listed on the website of the OIC's new human rights commission under "OIC Human Rights Related Instruments and Texts" and comes before other international human rights documents. See Organization of Islamic Cooperation, Legal Instruments, INDEP. PERMANENT HUMAN RIGHTS COMM'N: ORG. OF ISLAMIC COOPERATION, http://www.oic-iphrc.org/en/legal/ (last visited Mar. 5, 2017). Numerous additional examples highlighting the ongoing application and centrality of the CDHRI are discussed in Parts III and IV below. See infra notes 73, 128, 216, 224, and 229 (discussing OIC follow up on the CDHRI, follow up and coordination of OIC human rights work, the OIC human rights commission mandate, the OIC women's development organization, the OIC human rights commission's use of the CDHRI, and the evolving nature of rights protections provided under the CDHRI).

59 Iyad Ameen Madani, Org. of Islamic Cooperation Sec'y Gen., Statement at the Fourth Session of the OIC Independent Permanent Human Rights Commission (IPHRC) (Feb. 2, 2014). 


\section{LAYING THE FOUNDATION FOR HUMAN RIGHTS “MAinstreaming" AT THE OIC: NeW POLICIES AND InSTITUTiONS}

\section{A. A Ten Year Program of Action and Much Ado About Islamic HUMAN RIGHTS COVENANTS}

The 1972 OIC Charter and the 1990 CDHRI represent the OIC's first foray into international engagement on the substance of human rights. As time passed, the organization elaborated its initially hesitant policy in this area. In 2005, the OIC announced a milestone ten-year strategic action plan (Ten Year Program) intended to set out the challenges facing the Muslim world and the "means to address them." The document explicitly recognizes the principle of equality in two key places. First, under the heading "Human Rights and Good Governance," the Program calls to "[s]eriously endeavor to enlarge the scope of political participation, ensure equality, civil liberties and social justice and to promote transparency and accountability, and eliminate corruption in the OIC Member States." the equality to be guaranteed, and leaves open the question of whether such equality would apply to all individuals without distinction of any kind or be limited in some way.

The Ten Year Program's second reference to equality, however, overtly betrays that the OIC's conceptualization of equality falls short of that established by international human rights law (IHRL). Under a provision entitled "Rights of Women, Youth, Children, and the Family in the Muslim World," the Program calls for "strengthen[ing] laws aimed at enhancing the advancement of women in Muslim societies ... in accordance with Islamic values of justice and equality." 62 The provision also urges "adhering to the provisions of the Convention on the Elimination of all Forms of Discrimination against Women [CEDAW], in line with the Islamic values of justice and equality." ${ }^{\prime 3}$

Although the document invokes CEDAW ${ }^{64}$ in framing women's equality, making treaty compliance contingent on vague principles of religious law undercuts the quest for women's equality. The international

60 OIC TEN YEAR PROGRAM, supra note 10, at introduction.

${ }^{61} I d$. at $\S 1(\mathrm{VIIII})(1)$.

${ }^{62} I d$. at $\S 2(\mathrm{VI})(1)$.

${ }^{63} \mathrm{Id}$.

${ }^{64}$ U.N. Convention on the Elimination of All Forms of Discrimination against Women, 1979, 1249 U.N.T.S. 13 (Dec. 18, 1979) [hereinafter CEDAW]. 
community-including OIC states-had been explicitly alerted to this basic proposition almost a decade prior to adoption of the Ten Year Program. In 2000, the UN Human Rights Committee (HR Committee) concluded:

Inequality in the enjoyment of rights by women throughout the world is deeply embedded in tradition, history and culture, including religious attitudes. States parties should ensure that traditional, historical, religious or cultural attitudes are not used to justify violations of women's right to equality before the law and to equal enjoyment of all . . rights [under the ICCPR]. ${ }^{65}$

Even before the HR Committee's statement, OIC states were on notice that ill-defined religious norms represented unacceptable standards for defining or enforcing women's equality. When certain OIC states attached Shari'ah-based reservations to their ratification of CEDAW, ${ }^{66}$ other state parties filed objections challenging the validity of invoking religious law to limit application of the treaty. For example, in rejecting Libya's CEDAW reservation, Norway argued that downgrading treaty responsibilities

by invoking religious law (Shariah), which is subject to interpretation, modification, and selective application in different states adhering to Islamic principles, may create doubts about the commitments of the reserving state to the object and purpose of the Convention. It may also undermine the basis of international treaty law. ${ }^{67}$

In 1998, the CEDAW Committee reached a similar conclusion regarding the invalidity of Shari'ah-contingent reservations. The Committee's statement on reservations first recalled the deleterious effect of reservations generally, commenting they impact the efficacy of the treaty, prevent the Committee from assessing progress on

65 U.N. Human Rights Comm., CCPR General Comment No. 28: Article 3 (The Equality of Rights Between Men and Women), U.N. Doc. CCPR/C/21/Rev.1/Add.10, If 5 (2000).

66 "The greatest proportion of substantive reservations to CEDAW has been entered by States parties that cite Sharia (a) as a basis of all state law; or (b) as regulating matters of personal status (marriage, divorce, custody, guardianship and adoption, inheritance)." Marsha A. Freeman, Reservations to CEDAW: An Analysis for UNICEF, UNICEF 6 (Dec. 2009), http://www.unicef.org/gender/files/Reservations_to_CEDAW-an_Analysis_for_UNICEF.pdf.

67 Convention on the Elimination of All Forms of Discrimination against Women, Declarations, Reservation and Objections to CEDAW, CEDAW Sessions http://www.un.org/womenwatch/daw/cedaw/reservations-country.htm\#N38 (last visited Mar. 5, 2017) (Norway objecting to the reservation made by Libya on Jul. 16, 1990). Libya's reservation provided that its "[Accession] is subject to the general reservation that such accession cannot conflict with the laws on personal status derived from the Islamic Shari'ah.” 
implementation, and potentially undermine the entire human rights regime. ${ }^{68}$ The Committee then went further, observing:

Some States are concerned about a perceived conflict between article 2 [requiring measures to eliminate discrimination] and the Islamic shariah law. In other instances, States have entered reservations, which, although unspecific, are broad enough to encompass article 2. These reservations pose an acute problem for the implementation of the Convention and for the Committee's ability to monitor compliance with it. ${ }^{69}$

Despite clear existing guidance from the HR Committee and CEDAW Committee that Shari'ah-based limitations are not a legitimate justification for circumscribing women's equality, the OIC's Ten Year Program plainly reasserts the intent to press forward with an understanding of equality grounded in the same vague Islamic values. For example, the Program calls for the OIC CFM "to consider the possibility of establishing an independent permanent body to promote human rights in the Member States, in accordance with the provisions of the [CDHRI]." ${ }^{, 70}$ It likewise reaffirms the idea of establishing a parallel "Islamic" rights regime by urging "the elaboration of an OIC Charter for Human Rights," expediting development of " $[\mathrm{t}]$ he Covenant on the Rights of Women in Islam' in accordance with ... the [CDHRI]," ${ }^{, 71}$ and "encourag[ing] Member States to sign and ratify the OIC Covenant on the Rights of the Child in Islam." 72

The move to integrate references to nascent OIC "covenants" in the Ten Year Program reconfirms the organization's desire to build upon the CDHRI's declaratory nature and translate its principles into legally binding human rights instruments intended to regulate member state behavior in accordance with Islamic norms. This position is elaborated in OIC Resolution No. 60/27-P On the Follow-Up of the Cairo Declaration on Human Rights in Islam, adopted in June 2000, which recognizes,

68 U.N. GAOR, 19th Sess., UN Doc. A/53/38/Rev.1 (Jul. 10, 1998).

69 Id. Committee concluding observations for individual state parties with Shari'ah-based reservations reinforce the incompatibility of such measures with CEDAW. For example, the Committee's conclusions for Bahrain observe that "[Shari'ah] reservations are contrary to the object and purpose of the Convention. . The Committee strongly encourages the State party to. . take all necessary steps for the withdrawal of all its reservations to the Convention so as to ensure that women in Bahrain benefit from all the provisions enshrined in the Convention." UN Doc. CEDAW/C/BHR/CO/2, IITI15-16 (Nov. 7, 2008).

70 OIC TEN YEAR PROGRAM, supra note 10, at § 1(VIII)(2).

${ }^{71} I d$. at $\S 2(\mathrm{VI})(3)$.

$72 I d$. at $\S 2(\mathrm{VI})(6)$. 
among other things, "the importance of following up the [CDHRI] and calls upon the Governmental Expert Group ... to start the formulation and consideration of Islamic charters on human rights . . . each of which shall deal with one or several issues in detail based on the provisions of the [CDHRI]." ${ }^{73}$

This ongoing effort to shift from aspirational to binding normsreinvigorated with the Ten Year Program's call for "elaborating an OIC Charter for Human Rights" "74_ is further demonstrated by the OIC's 2004 endorsement of a standalone Covenant on the Rights of the Child in Islam (CRCI). ${ }^{75}$ The CRCI mirrors the UN Convention on the Rights of Child (UNCRC) ${ }^{76}$ in a number of ways. For example, the CRCI details numerous rights relating to children and calls for establishing a committee to monitor the progress of member states in implementing the treaty. ${ }^{77}$ Beyond these similarities, the CRCI's departure point and framing of rights is decidedly different. The document affirms "the Dhaka Declaration on Human Rights in Islam... and the Cairo Declaration on Human Rights in Islam," 78 and then proceeds to: (1) situate Shari'ah and domestic law above any international norms relating to children's rights $;{ }^{79}(2)$ prohibit any form of expression that contradicts Shari'ah; ${ }^{80}$ (3) prohibit forms of dress deemed incompatible with Shari'ah; ${ }^{81}$ (4) permit parents "to exercise Islamic and humane supervision over the conduct of the child" ${ }^{\prime 2}$; and (5) obligate states to bar

73 OIC, Resolution No. 60/27-P On the Follow-Up of the Cairo Declaration On Human Rights in Islam, the Twenty-seventh Session of the Islamic Conference of Foreign Ministers (Session of Islam and Globalization), Kuala Lumpur, Malaysia, art. 2 (Jun. 27-30, 2000).

74 OIC TEN Year PROGRAM, supra note 10, § 1(VIII)(2).

75 Covenant on the Rights of the Child in Islam, OIC Doc. OIC/9-IGGE/HRI/2004/Rep.Final [hereinafter CRCI].

76 UN Convention on the Rights of the Child, G.A. Res. 44/25 (Nov. 20, 1989) [hereinafter UNCRC].

77 CRCI, supra note 75 , at art. 24(1).

78 Id. at preamble.

79 Id. at art. 3(1).

80 Id. at art. 9(1).

81 Id. at art. 12(2)(iv).

82 Id. at art. 9(2)(iv). This provision seemingly makes allowance for the corporal punishment of minors despite the UN Committee on the Rights of the Child decisively rejecting such a possibility under the UNCRC. According to the Committee, a "clear and unconditional prohibition of all corporal punishment" is required, and such a prohibition also precludes faithbased justifications: "practice of a religion or belief must be consistent with respect for others' human dignity and physical integrity. Freedom to practise one's religion or belief may be legitimately limited in order to protect the fundamental rights and freedoms of others." Comm. on the Rights of the Child, General Comment No. 8 (2006): The Right of the Child to Protection 
"[c]ultural, ideological, information and communication invasion which contradicts the Islamic Shari'a[h]." ${ } 3$

Overarching these concerning provisions, the broad drafting of CRCI article 1 suggests that the covenant purports to apply its religious precepts to all children living within the state, irrespective of their parents' or the child's own religious belief. ${ }^{84}$ Perhaps in part because of these concerns, by the end of 2013 only eight states had signed the convention, and only one-Gambia-deposited its instrument of ratification. ${ }^{85}$ Nevertheless, the OIC continues to prop up the CRCI as good law. For example, the 2012 Islamic Conference of Ministers in Charge of Childhood called on Member States "to implement the [CRCI] through enacting laws, devising policies and programmes for better and rapid development of early childhood in the Islamic world, and highlighting the Islamic perspective in such policies and programmes." ${ }^{86}$ During a 2016 UN meeting on the rights of the child, the OIC boasted that it

attaches great importance to the promotion and protection of the rights of the child. ... Article 17 of the Covenant on the Rights of the Child in Islam . . . invites States Parties to take necessary measures to protect the child from all forms of abuse and particularly sexual abuse. ${ }^{87}$

In addition, in 2016, the OIC Islamic Summit's Final Communique "called on Member States to expedite the signing and ratification of the

from Corporal Punishment and Other Cruel or Degrading forms of Punishment (arts. 19; 28, para. 2; and 37, inter alia), IIII 29, 39, U.N. Doc. CRC/C/GC/8 (Mar. 2, 2007).

83 CRCI, supra note 75, at art. 17(4).

${ }^{84}$ Art. 1 provides: "For the purposes of the present Covenant, a child means every human being who, according to the law applicable to him/her, has not attained maturity." Id. at art. 1 . However, the CRCI also allows for member states to extend lesser protections to refugee children. Id. at art. 21.

85 Rep. of the Secretary General on Legal Affairs, submitted to the 40th Session of the Council of Foreign Ministers, OIC Doc. OIC/CFM-40/2013/LEG/SG-REP, Annex, IIII (R), (S) (Dec.2013).

86 Third Islamic Conference of Ministers In Charge of Childhood, Reinforcing Development: Meeting the Challenge of Early Childhood Promotion in the Islamic World" "II 11, Res. ICMCC3/2011/R.2.2 (Feb. 10-11, 2011) (The conference's final outcome document, the "Tripoli Declaration on Accelerating Early Childhood Development in the Islamic World", likewise reaffirmed "the CRCI, the Declaration on the Rights and Care of the Child in Islam. . . [and] the international Convention on the Rights of the Child.").

87 OIC Delegation Statement during the Annual full-day meeting on the rights of the child "Information and communications technology and child sexual exploitation" (Afternoon panel: Combating and preventing child sexual exploitation through ICTs- Role of ICTs, multistakeholders approach and good practices) (Mar. 7, 2016), https://extranet.ohchr.org/sites/hrc/HRCSessions/RegularSessions/31stSession/OralStatements/2 7_OIC_Panel_mtg_19.pdf. 
Covenant of the Rights of the Child in Islam." 88 From the OIC's perspective, therefore, the CRCI continues to embody a valid expression of desired human rights norms despite the fact that the covenant's substance diminishes international protections and perpetuates many of the same shortcomings embodied in the CDHRI.

Although the OIC succeeded in drafting and opening the CRCI for signature and ratification, it has achieved significantly less progress to date on the "Covenant on the Rights of Women in Islam" (CRWI). The Ten Year Program calls for expediting the CRWI's development, ${ }^{89}$ but this particular covenant remains - to borrow a computer industry term-vaporware. Still, despite these apparent setbacks, the OIC continued to reiterate that member states support the ratification (and drafting, in the case of the CRWI) of both treaties throughout the duration of the Ten Year Program. Most recently for example, in two separate resolutions issued following the 2015 CFM session, the OIC once again appealed to member states to sign and ratify the CRCI "as soon as possible" and reiterated the "urgent need to adopt" the CRWI. ${ }^{91}$

\section{B. Old Wine, New Bottle? A New Organizational Charter AND A REBRANDED OIC}

In addition to charting increased engagement with human rights (at least in some form), the OIC's Ten Year Program also called for restructuring the organization, changing its name, and revising its Charter and activities. ${ }^{92}$ In 2008, the organization formally adopted its new institutional Charter. ${ }^{93}$ This document carries over much from its

${ }^{88}$ O.I.C. Doc. OIC/13TH SUMMIT 2016/FC/FINAL, supra note 14, at If 194.

89 OIC TEN Year PRogram, supra note 10, § 2(VI)(3).

90 Council of Foreign Ministers Res. 1/42-LEG, On Follow-Up and Coordination of Action in the Field of Human Rights, If 19, OIC Doc. OIC/CFM-42/2015/LEG/RES/FINAL (May 27-28, 2014); see also Council of Foreign Ministers Res. 1/41-LEG, On the Follow-Up and Coordination of Work in the Field of Human Rights, If 18, OIC Doc. OIC/CFM41/2014/LEG/RES/FINAL (June 18-19, 2014).

91 Council of Foreign Ministers Res. 4/42-C, On Social and Family Issues, II B(10), O.I.C. Doc. OIC/CFM-42/2015/CS/RES/FINAL (May 27-28, 2015). The OIC passed similar resolutions in 2014 and 2013. See Council of Foreign Ministers Res. 4/41-C, On Social and Family Issues, If A(10), OIC Doc. OIC/CFM-41/2014/CSF/RES/ (Jun. 18-19, 2014); see also Council of Foreign Ministers Res. 4/40-C, On Social and Family Issues, II A(10), OIC Doc. OIC/40CFM/2013/CS/RES/FINAL (Dec. 9-11, 2013).

92 The organization changed its name from "Organization of the Islamic Conference" to "Organization of Islamic Cooperation." OIC TEN Year Program, supra note 10, § 1(XI)(1).

932008 OIC Charter, supra note 6. 
1972 predecessor but in certain respects arguably goes further to acknowledge and incorporate human rights language. The 2008 Charter arguably also represents a breakthrough in legitimacy and representativeness for the organization. As then OIC Secretary General Ihsanoglu reported to the CFM in 2010:

I am pleased to inform your august gathering that the OIC new Charter ... has now been signed by 39 States and ratified by 14 . Whereas the Old Charter did not get more than 23 signatures over its 40 years of existence. This is an indicator of the Member States' increased interest in their organization and their belief in its credibility and its being worthy of their service. ${ }^{94}$

On equality, the 2008 Charter retains its overriding preoccupation with member state equality rather than acknowledging equality as a human right ascribed to individuals. ${ }^{95}$ Still, for the first time the new document's preamble does reference a general determination to "preserve and promote the lofty Islamic values of peace, compassion, tolerance, equality, justice and human dignity." 96 In addition, the 2008 Charter also establishes new core objectives for the OIC that were previously outside of its formal mandate. These objectives include:

12. To protect and defend the true image of Islam, to combat defamation of Islam and encourage dialogue among civilisations and religions;

$\cdots$

14. To promote and to protect human rights and fundamental freedoms including the rights of women, children, youth, elderly and people with special needs as well as the preservation of Islamic family values;

15. To emphasize, protect and promote the role of the family as the natural and fundamental unit of society; [and]

16. To safeguard the rights, dignity and religious and cultural identity of Muslim communities and minorities in non-Member States. ${ }^{97}$

The difficulty with these provisions is that they are not linked expressly to any international human rights norm baseline. Other relevant Charter provisions further aggravate this disconcerting reality. For example,

94 Ihsanoglu, supra note 24, at 11.

952008 OIC Charter, supra note 6, at arts. 2(2), 16.

96 Id. at preamble.

97 Id. at arts. 1(12), (14-16). 
article 2(7) calls upon member states to "uphold and promote, at the national and international levels, good governance, democracy, human rights and fundamental freedoms, and the rule of law." 98 Yet, the Charter fails to establish the precise standard that will be used to measure such conduct. The preamble provides some direction here inasmuch as it links the understanding of human rights norms to the constitutional and legal systems of member states and likewise calls for promoting the "rights of women and their participation in all spheres of life, in accordance with the laws and legislation of Member States." 99 This guidance would suggest that any definition of human rights obligations or limits is to be linked to the member state's domestic legal framework rather than to international law.

The fact that the OIC grants common domestic legislation supremacy over international norms in the area of human rights is intentional and cannot be considered mere oversight or default practice. In several places elsewhere in the new Charter, the OIC exclusively invokes international law as the baseline for establishing certain other norms. For example, the Charter relies on international law to authenticate the principles of non-interference in domestic affairs, ${ }^{100}$ sovereignty and territorial integrity, ${ }^{101}$ and the right of peoples to selfdetermination. ${ }^{102}$

Finally, the 2008 Charter advances the Ten Year Program's call to establish an independent permanent human rights body for the $\mathrm{OIC}^{103}$ by recognizing a new official OIC organ ${ }^{104}$ - the Independent Permanent Human Rights Commission (IPHRC) - and authorizing its mandate to "promote the civil, political, social and economic rights enshrined in the organisation's covenants and declarations [presumably including the CDHRI] and in universally agreed human rights instruments, in conformity with Islamic values." 105 Despite its inclusion in the Charter, the IPHRC effectively did not emerge until 2011, when member states agreed to its operating statute.

98 Id. at art. 2(7)

99 Id. at preamble.

${ }^{100} I d$. at art. 2(5).

${ }^{101} I d$. at art. 1(4).

${ }^{102} I d$. at art. 1(7).

103 OIC TEN YeAR PROGRAM, supra note 10, at $\S 1$ (VIII)(2).

1042008 OIC Charter, supra note 6, at art. 5.

${ }^{105} I d$. at art. 15. 


\section{THE OIC’S “INDEPENDENT” PERMANENT HumAn RIGHTS COMMISSION}

Three years after being approved in principle by the OIC's new Charter, the 38th CFM Session in Kazakhstan officially gave life to the OIC's human rights commission. Acting under Resolution 2/38-LEG, the CFM adopted the IPHRC's statute and authorized the Commission to commence its operations. ${ }^{106}$ According to then Secretary General Ihsanoglu, this body would boost the OIC's international credibility and help increase its confidence. ${ }^{107}$ In his view, the event was nothing short of momentous, "[i]t is only appropriate that a year marked by popular uprising in different parts of the Muslim world against injustice, corruption and abuse of power should conclude with the landmark establishment of a Human Rights Commission duly equipped with a progressive vision and mandate."108

A closer examination of the IPHRC's statute and the Commission's activities to date, suggests a less progressive vision and more inauspicious start for the meaningful advancement of equality and nondiscrimination within the OIC system. To begin, the IPHRC statute sets out that the Commission will be "composed of 18 members nominated by the Member States' governments among experts of established distinction in the area of human rights." ${ }^{109}$ The statute also requires Member States to "encourage the nomination of women to the membership of the Commission." "110 Yet, despite this positive prompting, elected commissioners to date demonstrate an inconsistent - and in some cases non-existent-level of human rights expertise. ${ }^{111}$ Moreover, from its outset, men have dominated the Commission, with only four of the

${ }^{106}$ Council of Foreign Ministers Res. 2/38-LEG, OIC Doc. OIC/CFM-38/2011/LEG/RES/FINAL, arts. 1-2 (Jun. 28-30, 2011).

${ }^{107}$ Marie Juul Petersen, Islamic or Universal Human Rights? The OIC's Independent Permanent Human Rights Commission, 3 DIIS REPORT 10 (2012).

${ }^{108}$ Id. at 10 .

${ }^{109}$ OIC Doc. OIC/IPCHR/2010/STATUTE, art. 3 (2010) [hereinafter IPHRC Statute].

${ }^{110}$ This language appears weak in comparison with the requirement provided in article 7 for ensuring regional equity: "In the election of the experts due consideration shall be given to equitable geographical distribution among Member States." Id. at arts. $6 \& 7$.

${ }^{111}$ A listing of current commissioners and biographies is available on the IPHRC website. For example, the biographies of Raihanah Abdullah and Abdul Wahab make no mention of human rights. See About IPHRC, IndeP. Permanent Human Rights COMm'n, http://www.oiciphrc.org/en/about/ (last visited Mar. 4, 2017). 
original eighteen appointed commissioners being women, and this level of gender inequity continued into $2016 .{ }^{112}$

Beyond this failure to secure human rights expertise and gender equality, the IPRHC statute is defective for two principal reasons. First, it remains anchored to the CDHRI vision of rights, notwithstanding the argument by some that it attempts to move beyond this OIC touchstone. Second, despite its impressive title, the substance of the statute ensures that the commission will be hobbled by a near total lack of independence. These shortcomings give rise to serious questions about the underlying purpose of the IPHRC and its mandate, and suggest the commission will be used not to promote and protect universal human rights within the OIC system, but rather to deflect international criticism of its members and-particularly for the purposes of this article-to amplify the OIC's effort to challenge any universal entrenchment of international human rights norms, including equality and nondiscrimination.

\section{IPHRC Mandate Anchored to CDHRI Relativism}

Although the IPHRC statute's preamble makes plain the Commission's raison d'être is grounded in the CDHRI, ${ }^{113}$ its operative paragraphs omit any explicit reference to the Cairo Declaration. ${ }^{114}$ This fact, coupled with the anonymous assurance of one IPHRC staffer that "the Cairo Declaration is a declaration, the human rights commission is a statutory commission-you decide what is most important," 115 appears to have led at least one observer to assert, "there can be no doubt that the Commission relies on a conception of human rights that is closer to the UN Declaration on Human Rights." 116 Substantiating such an important pronouncement demands more rigorous investigation.

Despite the IPHRC statute's apparently nominal invocation of the CDHRI, it remains shrouded in the Declaration's relativistic shadow,

\footnotetext{
${ }^{112}$ Council of Foreign Ministers Res. 7/38-ORG, On the Election of Members of the OIC Independent Permanent Human Rights Commission, arts. 1, OIC Doc. OIC/CFM38/2011/ORG/RES (Jun. 28-30, 2011).The original female IPHRC commissioners were: Ilham Ibrahim Ahmed Mohamed (Sudan); Siti Ruhaini Dzuhayatin (Indonesia); Raihanah Abdullah (Malaysia); and Asila Wardak (Afghanistan). These four commissioners have had their terms renewed and continue to be the only female IPHRC members. About IPHRC, supra note 111.

${ }^{113}$ IPHRC Statute, supra note 109, at preamble.

${ }^{114} I d$.

${ }^{115}$ Petersen, supra note 107, at 29.

${ }^{116} I d$.
} 
where universal rights are conditioned on unspecified Islamic values. It bears recalling that the statute's preambulatory language originates in the 2008 OIC Charter, which affirmatively requires that the Commission promote the rights "enshrined in the organisation's covenants and declarations" (such as the CDHRI) and in universally agreed human rights instruments, "in conformity with Islamic values." 117 The statute therefore necessitates not only adoption of the CDHRI's baseline, but effectively translates its declaratory aspirations into legal norms by requiring the IPHRC to promote the rights as enshrined therein. This formulation casts doubt on the argument that the Commission's starting point for human rights is aligned with the international norms. Furthermore, it renders hollow the IPHRC staffer's assurance that the Commission's statutory status will somehow trump the CDHRI, since its obligation to promote the CDHRI is equally blessed with the same statutory authority.

The duty imposed by the 2008 Charter and the IPHRC statute preamble further obligates the Commission to promote norms emerging from the OIC's ongoing efforts to formulate a set of Islamic human rights treaties. Presumably, this would include treaties such as the envisioned CRWI and the already open to ratification CRCI. The latter covenant "[a]ffirm[s] the principles contained in ... the [CDHRI]" 118 and requires parties to "respect the provisions of the Islamic Shari'a, and observe the domestic legislations of the Member States." 119 This affirmation - together with the fact that the CRCI omits any operative reference to the UNCRC or other relevant international human rights treaty-underscores the deeply problematic nature of legitimating such instruments as authoritative human rights sources upon which the IPHRC's work is to be based.

The CDHRI's disconnect from universal human rights norms is rendered especially stark considering that the OIC's overarching approach to constructing its Islamic human rights regime is premised on a rejection of the pro homine principle governing the interpretation and application of international human rights norms. Under the pro homine principle, "all human rights legal instruments and customary norms must be interpreted and applied in the manner most protective of the human

\footnotetext{
${ }^{117}$ Neither the Charter nor the IPCHR statute provide an explanation for the term "Islamic values". See 2008 OIC Charter, supra note 6, at art. 15; see also IPHRC Statute, supra note 109, at preamble (emphasis added).

${ }^{118}$ CRCI, supra note 75 , at preamble.

${ }^{119} I d$. at art. 3(1).
} 
dignity of human beings, not the manner that is best for the state." ${ }^{120}$ As such, where competing or conflicting standards of protection may arise, states are required to uphold the maximum protection afforded to the individual right at issue. ${ }^{21}$

Manifestations of the pro homine principle are evident across key international human rights treaties. For example, Article 41 of the UNCRC provides:

Nothing in the present Convention shall affect any provisions which are more conducive to the realization of the rights of the child and which may be contained in:

(a) The law of a State party; or

(b) International law in force for that State. ${ }^{122}$

Likewise, the ICCPR, under art. 5, provides:

Nothing in the present Covenant may be interpreted as implying for any State, group or person any right to engage in any activity or perform any act aimed at the destruction of any of the rights and freedoms recognized herein or at their limitation to a greater extent than is provided for in the present Covenant.

There shall be no restriction upon or derogation from any of the fundamental human rights recognized or existing in any State Party to the present Covenant pursuant to law, conventions, regulations or custom on the pretext that the present Covenant does not recognize such rights or that it recognizes them to a lesser extent. ${ }^{123}$

A variety of national constitutions ${ }^{124}$ and other regional human rights treaties similarly prioritize the norm that most robustly protects

${ }^{120}$ H. Victor Condé, A HANDBook of InTERnAtional Human Rights TERminOlogy, 107 (2d ed. 2004) (definition for Hominum Causa Omne Jus Constitutum Est (Principle of Interpretation and Application of Treaties) also known as the principle of Pro Homine). Condé defines the pro homine principle as requiring "international human rights norms [to] be interpreted and applied in a way that most fully and adequately protects human beings. And where more than one human rights norm or instrument applies to a particular situation, the one that gives the most protection or freedom to the individual should prevail over those offering less." Id. at 207.

${ }^{121}$ Allan R. Brewer-Carías, Constitutional Protection of Human Rights in Latin America: A Comparative StUdy OF AMPARo PROCEedingS, 59 (2008) (observing "in cases involving various provisions, the one that should prevail is the one that contains the more favorable regulation.").

${ }^{122}$ UNCRC, supra note 76, at art. 41.

${ }^{123}$ ICCPR, supra note 34, at art. 5.

${ }^{124}$ For example, Mexico's constitution provides “provisions relating to human rights shall be interpreted according to this Constitution and the international treaties on the subject, working in favor of the broader protection of people at all times." Constitución Política de los Estados 
individual rights, further isolating the OIC's effort to give preference to less protective domestic and religious law. For example, article 29 of the American Convention of Human Rights provides that none of its provisions shall be interpreted as:

a. [P] ermitting any State Party, group, or person to suppress the enjoyment or exercise of the rights and freedoms recognized in this Convention or to restrict them to a greater extent than is provided for herein; [and]

b. [R] estricting the enjoyment or exercise of any right or freedom recognized by virtue of the laws of any State Party or by virtue of another convention to which one of the said states is a party; ${ }^{125}$

The European Union (EU) Charter of Fundamental Rights similarly stipulates:

Nothing in this Charter shall be interpreted as restricting or adversely affecting human rights and fundamental freedoms as recognised, in their respective fields of application, by Union law and international law and by international agreements to which the Union or all the Member States are party, including the European Convention for the Protection of Human Rights and Fundamental Freedoms, and by the Member States' constitutions. ${ }^{126}$

Any lingering doubt over the nature of the IPHRC statute is put to rest by examining OIC Resolution No. 1/38-Leg on Follow Up and Coordination of Work on Human Rights. ${ }^{127}$ Passed alongside the IPHRC statute in 2011, this resolution reaffirms the OIC's commitment to

Unidos Mexicanos [CPEUM], art. 1(2), Diario Oficial de la Federación [DOF] 1917, 2015 (Mex.); see also Víctor Manuel Collí Ek, Improving Human Rights in Mexico: Constitutional Reforms, International Standards, and New Requirements for Judges, 20 HUMAN RIGHTS BRIEF 1, 3 (2012) (citing Id. "Las normas relativas a los derechos humanos se interpretarán de conformidad con esta Constitución y con los tratados internacionales de la materia favoreciendo en todo momento a las personas la protección más amplia.”).

125 American Convention on Human Rights, art. 29, Nov. 21, 1969, 1144 U.N.T.S. 143. See Valerio de Oliveira Mazzuoli \& Dilton Ribeiro, Indigenous Rights before the Inter-American Court of Human Rights: A Call for a Pro Individual Interpretation, 4 RJLB 1707 (2015). http://www.cidp.pt/publicacoes/revistas/rjlb/2015/4/2015_04_1707_1743.pdf (For a longer treatment addressing the use of the pro homine principle by the Inter-American Court of Human Rights). The Inter-American Commission on Human Rights similarly acknowledges that its work is informed by "the pro homine principle, whereby a law must be interpreted in the manner most advantageous to the human being." What is the IACHR?, INTER-AMERICAN COMMISSION ON HUMAN RigHTS, http://www.oas.org/en/iachr/mandate/what.asp (last visited Mar. 9, 2017).

${ }^{126}$ Charter of Fundamental Rights of the European Union, art. 53, Dec. 14, 2007, 2007 O.J. (C 303) 1 .

${ }^{127}$ Council of Foreign Ministers Res. 1/38-LEG, On Follow Up and Coordination of Work on Human Rights, OIC Doc. OIC/CFM-38/2011/LEG/RES/FINAL (Jun. 28-30, 2011). 
prioritizing Islamic human rights covenants and the continued centrality of the CDHRI. The resolution's preamble posits that the promotion and protection of human rights can occur only "with due regard to the "Cairo Declaration on Human Rights in Islam." "128 It then proceeds to endorse the ongoing "formulation of a set of Islamic covenants on human rights" as a way "to promote and protect human rights," 129 and further on promulgates "the right of States to adhere to their religious, social, and cultural specificities." 130 This latter position stands in direct contravention of the "duty of States, regardless of their political, economic and cultural systems, to promote and protect all human rights and fundamental freedoms" established by the Vienna Declaration and Program of Action (VDPA). ${ }^{131}$ As Francine Fournier has pointed out, restricting universal human rights on the basis of religious specificities distorts the VDPA's central intent. She states,

The mention of particularities and various historical, cultural and religious backgrounds is sometimes interpreted as a sort of escape clause, as an argument for the failure to comply with human rights standards. This understanding ... does not take into account ... that states are duty-bound-regardless of their political, economic and cultural systems - to promote and protect all human rights. In line with this formulation - and this is important - cultural specificities should be taken into account in the promotion and protection of human rights. They should help to determine the most effective ways and means to overcome difficulties in the implementation of human rights and fundamental freedoms. ${ }^{132}$

OIC Resolution 1/38-LEG does not end with mere rejection of the possibility that universal human rights could trump specific religious values. Rather, it goes on to advocate the "non-use of the universality of human rights as a pretext to interfere in the states' internal affairs and

${ }^{128} I d$. at preamble.

${ }^{129} \mathrm{Id}$.

${ }^{130} I d$. at art. 4.

${ }^{131}$ World Conference on Human Rights, Vienna Declaration and Programme of Action, §1(5), U.N. Doc. A/CONF.157/23 (Jun 25, 1993) [hereinafter VDPA].

${ }^{132}$ Francine Fournier, UNESCO and Human Rights, in PeACE, JustiCe AND FreEdOM: Human Rights Challenges For the New Millennium 383, 385 (Gurcharan Singh Bhatia et al. eds., 2000). Human Rights Watch's 1994 conclusion on cultural relativism is equally apt here: "suppressing freedom and equality in the name of culture or religion is a corruption of the concept of rights. . To view rights as varying with governmental interpretations of culture or religion is to eviscerate the power of rights." The Argument of Cultural Relativism, HUMAN RIGHTS WATCH WORLD REPORT 1994, https://www.hrw.org/reports/1994/WR94/Intro-03.htm (last visited Mar. 9, 2017). 
diminish their national sovereignty." 133 Thus, the OIC not only distorts the compromise struck at the international level to uphold universal human rights norms in the face of national and regional particularities and historical, cultural and religious backgrounds (embodied in the VDPA), but it also repudiates the legitimacy of external scrutiny of domestic implementation of these norms.

This position contradicts longstanding international practice in the area of universal human rights, which Nigel Rodley has traced back to Sir Hersch Lauterpacht. As early as 1950, Lauterpacht "argued that mere discussion of a state's human rights performance was not precluded under the [UN] Charter's non-intervention rule." ${ }^{134}$ Wider and more concrete endorsement of this understanding has followed. For example, in 1989 the Institute of International Law concluded that "a State acting in breach of its obligations in the sphere of human rights cannot evade its international responsibility by claiming that such matters are essentially within its domestic jurisdiction." ${ }^{135}$ Further, in the face of such breaches, other states "are entitled to take diplomatic, economic and other measures towards [the violating] State ... provided such measures are permitted under international law. ... These measures cannot be considered an unlawful intervention in the internal affairs of that State." ${ }^{136}$ Nearly twenty five years ago, OSCE participating states "categorically and irrevocably declare[d] that the commitments undertaken in the field of [human rights] are matters of direct and legitimate concern to all participating States and do not belong

${ }^{133}$ OIC Resolution No. 1/38-LEG, supra note 127, at art. 5. The CRCI mirrors this noninterventionist approach, providing that to "achieve the objectives [of treaty] it is incumbent to . . Observe non-interference in the internal affairs of any State." CRCI, supra note 75, at art. $3(5)$.

${ }^{134}$ Nigel Rodley, United Nations Human Rights Treaty Bodies and Special Procedures of the Commission on Human Rights - Complementarity or Competition?, in TOWARDS IMPLEMENTING UniVERSAL Human Rights: FeSTSCHRIFT FOR THE TWENTY-FIFTH ANNIVERSARY OF THE Human Rights Committee 3, 4-5 (Nisuke Andō ed., 2004). Jack Donnelly similarly rejects what he labels a "statist (or legalist)" view that "an active concern for the human rights practices of other states [is] inconsistent with the fundamental principle of state sovereignty." According to him, "[i]llegitimate intervention occurs only when influence is exercised through strongly coercive, essentially dictatorial means. So long as such means are avoided, statism provides no ground for excluding human rights concerns from foreign policy.” Jack Donnelly, UNIVERSAL HUMAN RIGHTS IN THEORY AND PRACTICE, 155, 158 (2003).

${ }^{135}$ The Inst. of Int'l Law, Resolution on the Protection of Human Rights and the Principle of Nonintervention in Internal Affairs of States, art. 2, (1989), http://www.idiiil.org/idiE/resolutionsE/1989_comp_03_en.PDF.

${ }^{136}$ Id. at art. 2. 
exclusively to the internal affairs of the State concerned." ${ }^{137}$ Based on this undertaking, fifty-six nations from Europe, Central Asia, and North America committed themselves "no longer ... to invoke the nonintervention principle to avoid discussions about human rights problems within their countries." 138 As argued elsewhere, state parties to the ICCPR and other major international human rights treaties similarly recognize this basic premise by virtue of accepting the reporting obligations that come with treaty ratification. ${ }^{139}$

\section{Branding Effort Aside, IPHRC Statute Ensures Commission Will Be Anything but Independent (or Pluralist)}

The OIC had a variety of favorable human rights mechanisms to consider in drafting the IPHRC's statute. Yet these potential modelsranging from national human rights institutions (NHRIs) to other regional mechanisms - appear to have made little impression on the drafters. Although the Commission itself purports to follow internationally recognized standards for ensuring "objectivity, independence and professionalism in the performance of its mandated tasks," 140 the IPHRC's founding statute makes plain the OIC's determination to ensure that the human rights body remain dependent upon OIC member states and limited to serving the OIC's political objectives.

As discussed above, the statute's framing of human rights is decidedly relativistic and risks disconnecting the Commission from the universal norms set out on the international level. The statute is flawed in

\footnotetext{
${ }^{137}$ Org. for Sec. \& Co-operation in Eur. (OSCE), Document of the Moscow meeting of the Conference on the Human Dimension of the CSCE, preamble (Oct. 4, 1991), http://www.osce.org/odihr/elections/14310?download=true.

${ }^{138}$ OSCE Office for Democratic Insts. \& Human Rights, OSCE HUMAN DIMENSION COMmitMents: A REFERENCE GuIDE, xvi http://www.iskran.ru/cd data/disk2/r3/015.pdf.

${ }^{139}$ Blitt, supra note 15 , at 171 Notably, only seven of the OIC's 57 member states have opted to forgo ratification of the ICCPR: Brunei, Comoros, Malaysia, Oman, Qatar, Saudi Arabia, and the United Arab Emirates. Ratification Status of ICCPR, U.N. TREATY COLleCtion, https://treaties.un.org/Pages/ViewDetails.aspx?src=IND\&mtdsg_no=IV-

$4 \&$ chapter $=4 \&$ clang=_en (last visited Mar. 5, 2017). Over 110 states have also ratified the ICCPR's optional protocol recognizing the competence of the UN Human Rights Committee to receive and consider human rights complaints filed by individuals directly. Ratification Status of Optional Protocol to the ICCPR, U.N. TREATY COLLECTION, https://treaties.un.org/Pages/ViewDetails.aspx?src=IND\&mtdsg_no=IV-

$5 \&$ chapter $=4 \&$ clang=_en (Last visited Mar. 5, 2017).

${ }^{140}$ About IPHRC, supra note 111.
} 
other ways that similarly operate to downgrade the Commission's legitimacy and ability to operate in any independent or constructive manner. Among other things, the IPHRC statute ensures the Commission will be reliant on member states and the OIC CFM in defining the scope of its activities and executing its mandate. For example, article 12 requires that the Commission "carry out consultative tasks for the Council," and article 13 obligates the Commission to "support the OIC's position on human rights at the international level" rather than serve as an independent engine of individual rights monitoring and protection.

The IPHRC's mandate is further restricted under article 10, which appears to authorize the Commission to conduct open-ended monitoring "of the human rights of Muslim communities and minorities" that are outside of OIC member states. Articles 14 and 17 reinforce this reading insofar as they require that an OIC member state either authorize consultation or request cooperation with the IPHRC before the Commission can engage on internal human rights issues specific to that member state. ${ }^{141}$ The effect of these articles reveals an untenable hypocrisy. On one hand, the OIC seeks to perpetuate its core policy of non-interference in the internal affairs of its own member states by making IPHRC engagement contingent on member state permission. On the other, it discards the pretense of such a norm as it might apply outside of the OIC, by asserting the right to scrutinize non-OIC states that are home to Muslim communities. Article 17 also operates to limit the Commission's recommendation-making function as any proposals it puts forward must be restricted to "the OIC framework and in harmony with Islamic values and agreed international standards." 142

Finally, articles 20 and 21 of the IPHRC statute circumscribe the Commission's autonomy in two key areas. First, its independent ability to convene meetings is limited. The Commission is authorized to hold two annual meetings and extraordinary meetings are permitted only if requested by a member state or the Secretary General and approved by a majority vote of the OIC. ${ }^{143}$ Second, its independent ability to call upon expert testimony is similarly restricted. Participation of "guests" in IPHRC meetings, such as nongovernmental organizations (NGOs) and NHRIs, is contingent upon the approval of the Commission's host state,

\footnotetext{
${ }^{141}$ IPHRC Statute, supra note 109, at arts. 14, 17.

${ }^{142} I d$. at art. 17.

${ }^{143} I d$. at art. 18.
} 
Saudi Arabia. ${ }^{144}$ Taken together, these provisions operate to divest the Commission a priori of any functional independence from OIC states and thereby render moot the question of whether individual IPHRC commissioners may accurately be characterized as independent. ${ }^{145}$ Even if a given commissioner or group of commissioners is genuinely "independent," 146 the effectiveness of that independence is critically undermined by stripping the institution of the ability to call extraordinary meetings or request testimony from interlocutors without advance OIC approval.

The absence of functional independence is taken to the extreme given the IPHRC statute's unusual requirement that the OIC secretary general manage the task of hiring Commission staff, and a further restriction that limits this hiring ability to a list of candidates preapproved by member states. ${ }^{147}$ This additional layer of oversight underscores how committed the member states are to controlling all facets of the Commission's work at every level. Relevant to this - and in addition to the requirement that IPHRC Commissioners be MuslimOIC regulations restrict the Commission's staff to adherents of the Muslim faith, despite the presence of significant and diverse non-Muslim religious communities living within OIC member states. ${ }^{148}$

The IPHRC's bleak institutional framework and mandate are rendered more disappointing when juxtaposed against practices embraced by other national and regional human rights institutions. For example, Canada's Human Rights Act establishes a Human Rights Commission empowered to, inter alia:

${ }^{144} I d$. at art. 21.

${ }^{145}$ See Press Release, FIDH, ASEAN: Actions of the AICHR's Current Chair Demonstrate Need for AICHR's Terms of Reference to Ensure Independence and Impartiality of its Commissioners (Mar. 30, 2015), https://www.fidh.org/en/international-advocacy/other-regionalorganisations/asean/asean-actions-of-the-aichr-s-current-chair-demonstrate-need-for-aichr.

146 This assumption too is doubtful. Of the current eighteen serving IPHRC commissioners, at least half are active representatives of member states' governments. About IPHRC, supra note 111.

${ }^{147}$ IPHRC Statute, supra note 109, at art. 23.

${ }^{148}$ For example, job postings on the IPHRC website stipulate under "General Requirements" that applicants must "be a Muslim national of one of the OIC Member States." At the time of writing, two posts were available with the IPHRC, "Research Analyst" and "Protocol Officer"; both positions set out identical general requirements. This religious test corroborates reports the OIC maintains "an unwritten law that only Muslims from member countries are eligible for its jobs." Ahsan, supra note 7, at 56. The issue of pluralism might also be raised within the narrower confine of Islam to ask whether the Commission's composition genuinely represents all Muslims, including minority sects from within Islam, as well as other Muslim dissenters and nonbelievers. 
* Consider requests and recommendations concerning human rights and freedoms "from any source"; 149

* Review any parliamentary actions for consistency with principles of equality and nondiscrimination; ${ }^{150}$ and

* “[D]iscourage and reduce discriminatory practices" by persuasion, publicity or other means. ${ }^{151}$

To be certain, Canada's approach to designing and implementing its human rights commission has not occurred in a vacuum. Much of its substance is reflected in the Principles Relating to the Status of National Institutions (Paris Principles), a set of authoritative guidelines endorsed by the UN General Assembly in $1993 .{ }^{152}$ Although these principles do not reflect binding legal obligations, they "have been gradually recognised at the international, regional and domestic levels to the extent that they are now globally accepted criteria for NHRIs and are permanently cited in recommendations and declarations encouraging States to establish and strengthen such institutions." 153

The OIC's rejection of the Paris Principles is clear and consistent. With respect to purview, the Paris Principles recommend national institutions "be given as broad a mandate as possible" 154 to promote and ensure "harmonization of national legislation ... with international human rights instruments ... and their effective implementation." ${ }^{155}$ Yet, as discussed above, the IPHRC statute creates a commission that operates contingent on member state permission, that issues human rights recommendations disconnected from international instruments, and that is left powerless with respect to the task of ensuring effective implementation. Driving this point home, although apparently proposed, drafters of the IPHRC statute opted to strike a provision that would have empowered the Commission to "investigate any possible

\footnotetext{
${ }^{149}$ Canadian Human Rights Act, R.S.C. 1985, c. H-6, at art. 27(1)(e).

${ }^{150}$ Id. at art. 27(1)(g).

${ }^{151} I d$. at art. 27(1)(h).

${ }^{152}$ The first International Workshop on National Institutions for the Promotion and Protection of Human Rights originally adopted the principles in October 1991. GAUTHIER DE BECO \& RACHEL MurRay, A COMMENTARY ON THE PARIS PRINCIPLES ON NATIONAL HUMAN RightS INSTITUTIONS, 3-4 (2015).

${ }^{153} I d$. at 18.

${ }^{154}$ G.A. RES. 48/134, The Paris Principles, at 4 (Dec. 20, 1993).

${ }^{155} I d$. at 5 .
} 
human rights violations by the OIC Member States [and] submit reports thereon to the Council of Foreign Ministers for appropriate decision." 156

The IPHRC statute similarly rejects the Paris Principles' guidelines for ensuring institutional autonomy from government. These norms require human rights institutions to be free to "consider any questions falling within its competence," including those submitted "without referral to a higher authority, on the proposal of its members or of any petitioner," and to "hear any person and obtain any information and any documents necessary for assessing situations falling within its competence." 157 Despite this guidance, the IPHRC statute takes a restrictive approach to autonomy, first by forcing the Commission to approve "guests" unanimously (essentially granting individual commissioners veto power), and then by subjecting such "guests" to a second potential authorization veto by the Commission's host state, Saudi Arabia. ${ }^{158}$

Finally, the Paris Principles place an understandable emphasis on the independence and pluralism of the human rights institution. Thus, composition of the institution should be afforded "all necessary guarantees to ensure the pluralist representation of the social forces (of civilian society)." ${ }^{159}$ Furthermore, the institution's members should be empowered to "meet on a regular basis and whenever necessary." 160 As demonstrated, IPHRC members are neither pluralist with respect to gender or religious identity, nor are they truly independent of government control.

Admittedly, at the time of its drafting the ambit of the Paris Principles was envisioned as extending only to NHRIs. Yet, evidence suggests that many of its norms have come to govern the practice of human rights mechanisms operating on the regional level as well. For example, confronted with the institutional shortcomings of ASEAN's Intergovernmental Commission on Human Rights (AICHR), leading human rights NGOs have argued,

In developing a transparent [commissioner] selection process ... ASEAN member states [should] look to the appointment practices of other international bodies, as well as to the [Paris Principles] for guidance. The Paris Principles affirm the importance of consultations

\footnotetext{
156 PETERSEN, supra note 107, at 18.

${ }^{157}$ Paris Principles, supra note 154, at 3(b).

158 IPHRC Statute, supra note 109, at art. 21.

159 Paris Principles, supra note 154, at 1.

${ }^{160} I d$. at 3(d).
} 
with a broad variety of stakeholders, including civil society, as an important element in ensuring an independent process. The same principles should apply to a regional body such as AICHR. ${ }^{161}$

The EU has echoed the view that the Paris Principles are applicable and relevant to the formation of regional human rights mechanisms. For example, it has "encourage[d] ASEAN ... to align the operations of the AICHR in general adherence to the Paris principles, in order to protect the human right of all individuals in ASEAN."

The AICHR's failure to adopt the basic norms embodied under the Paris Principles (and enshrined in other regional human rights mechanisms, such as the Inter-American Commission on Human Rights and the African Commission on Human and People's Rights) ${ }^{163}$ may be traced back to the body's terms of reference. ${ }^{164}$ Among other things, this document establishes a substandard mandate for the human rights commission that: (1) is merely consultative (as opposed to investigatory); (2) prioritizes the principle of non-interference in the internal affairs of states; (3) weakens the independence of Commissioners by employing a substandard appointment process; and (4) lacks "a dedicated secretariat, consisting of competent, impartial and independent members." 165

Concerns over the AICHR's terms of reference make plain that the commission will be unable to operate as an authoritative human rights mechanism without significant changes to its mandate. More

\footnotetext{
${ }^{161}$ FIDH, supra note 145.

${ }^{162}$ Directorate-General for External Policies, The Role of Regional Human Rights Mechanisms, Directorate-General for External Policies Policy DePartment, 55 (Nov. 2010), http://www.europarl.europa.eu/RegData/etudes/etudes/join/2010/410206/EXPODROI_ET(2010)410206_EN.pdf.

${ }^{163}$ For example, the African Commission "may resort to any appropriate method of investigation; it may hear from . . . any other person capable of enlightening it", and states are directed "to submit every two years ... a report on the legislative or other measures taken, with a view to giving effect to the rights and freedoms recognised and guaranteed by the present Charter." Org. of African Unity [OAU], African Charter on Human and Peoples' Rights, arts. 46, 62, OAU Doc. CAB/LEG/67/3 rev. 5 (Jun. 27, 1981).

${ }^{164}$ See ASEAN Intergovernmental Commission on Human Rights, Terms of Reference (2009).

${ }^{165}$ Solidarity for Asian People's Advocacy Task Force on ASEAN \& Human Rights [SAPA TFAHR], Four Years On and Still Treading Water: A Report on the Performance of the ASEAN Human Rights Mechanism in 20134 (Atnike N. Sigiro et al. eds., 2014), http://www.forumasia.org/uploads/publications/2014/November/@s-Isi\%20Forum\%20Asia\%20Revisi.pdf. These criticisms are mirrored in the academic literature. See, e.g., Carole J. Petersen, Bridging the Gap? The Role of Regional and National Human Rights Institutions in the Asia Pacific, 13 ASIAN-PAC. L. \& POL'Y J. 174, 193 (2011) (concluding that the AICHR "will not receive individual complaints and it lacks any significant enforcement powers. Moreover, as an intergovernmental commission, the AICHR is not independent of the governments that established it.").
} 
importantly for the purposes of this article, the AICHR's defects mirror the problematic shortcomings set out above with respect to the IPHRC. Even if one were to maintain that the Paris Principles ought not to be applied to regional human rights mechanisms, ${ }^{166}$ additional evidence indicates that many of the same basic principles are already recognized and exist as standalone best practices or customary norms for regional institutions. To this point, a "non-paper" issued by the UN Office of the High Commissioner for Human Rights (OHCHR) suggests that regional human rights mechanisms should be "composed of members who are independent from government, and are impartial persons of integrity with a recognised competence in the field of human rights." 167 Further, these mechanisms should be "mandated to independently promote and protect human rights" 168 in accordance with specific minimum powers and responsibilities, including the ability to: (1) request human rights-related information from a State Party; (2) carry out on-site visits to investigate specific human rights concerns; (3) issue periodic progress reports; (4) receive, investigate, analyze and decide on communications from any individual, group of persons or NGO alleging human rights violation(s) by a State Party; and (5) obtain "all necessary information ... with a guarantee that the State Party will not engage in reprisals against those persons providing information to the mechanism." 169

Likewise, scholarship in this area confirms that regional human rights commission mandates should incorporate many of the same minimum norms already enshrined in the Paris Principles. For example, Heyns and Killander posit that powers ascribed to regional mechanisms should include:

1. On-site visits to investigate and report on the human rights situation in member states ....

${ }^{166}$ For example, the ASEM Seminar on Human Rights (made up of 113 participants representing governments and civil society across Asia and Europe) conceded that "While the Paris Principles may not be an appropriate model, there is value in exploring the development of minimum international standards for regional human rights mechanisms." Participants also concluded that "The principle of non-interference with the internal affairs of states. . is a real constraint to the promotion and protection of human rights." Seminar, National and Regional Human Rights Mechanisms, at 57 (Nov. 23-25, http://www.asef.org/images/docs/11th\%20Human\%20Rights\%20Publication_110612_v11\%20c omplete.pdf.

167 U.N. Office High Comm'r Human Rights Reg'l Office for S.E. Asia, Principles for Regional Human Rights Mechanisms (Non-Paper), http://bangkok.ohchr.org/programme/asean/principles${ }^{168} I d$ regional-human-rights-mechanisms.aspx (last visited Mar. 9, 2017).

${ }_{169} I d$. 
2. Appointment of independent special rapporteurs, working groups etc as may be needed.

3. Consideration and investigation of individual complaints in respect of alleged human rights violations by member states.

4. Publication and dissemination of reports and decisions .... Transparency should be the norm.

5. Interaction with civil society organizations, national human rights institutions and other international mechanisms with a human rights agenda. ${ }^{170}$

Measured against the Paris Principles and recognized best practices applicable to regional human rights institutions, the IPHRC statute falls far short. ${ }^{171}$ Rather than reflect a bona fide human rights commission, the IPHRC is poised instead to be useful to OIC member

${ }^{170}$ Christof Heyns \& Magnus Killander, Toward Minimum Standards for Regional Human Rights Systems, in LOOKING TO THE FUTURE: ESSAYS ON INTERNATIONAL LAW IN HONOR OF W. Michael Reisman, 544-45 (Mahnoush H. Arsanjani et al. eds., 2011) [hereinafter Heyns \& Killander]. The authors suggest that "Considering the multi-regional nature of the OIC, a limited promotional mandate appears to be advisable with deference to regional human rights systems where such exists and to the global system." Id. at 551. As this article argues, the IPHRC may to a limited extent do the former; but it falls flat on the latter. Heyns and Killander further observe that: "One of the complexities in developing a coherent regional human rights system under the OIC. . . is the multi-regional nature of this IGO. In addition to the UN human rights instruments, member states of the OIC are also party to the African Charter, the European Convention and the American Convention. Conflicting decisions could arise if the OIC was to expand its monitoring system." Id. at 558. The specter of such conflicts should not serve to legitimate a human rights mechanism that has the potential to undermine IHRL. In any case, such conflicts are not particularly unusual, and can be overcome by ensuring respect for the pro homine principle discussed above and the reasonable application of other legal tools such as the margin of appreciation.

${ }^{171}$ Indeed, the IPHRC appears to have more in common with the so-called "International Human Rights Commission," the bizarre and self-serving creation of Mr. Muhammad Shahid Amin Khan of Pakistan, a self-proclaimed "World Chairman," ambassador, and doctor. The International Human Rights Commission, among other things, has defended the conduct of the Assad regime of Syria, organized fraudulent beauty pageants in Lebanon, and, perhaps not coincidentally, counts former OIC head Ihsanoglu as one of the "co-presidents" of the organization's “Eminent Person's Council." Mike Nagoya, Syria: IHRC Chief Ambassador Dr. Muhammad Shahid Amin Khan, YouTuBE (Jan. 3, 2013), https://www.youtube.com/watch?v=Svp3Qa_kz0o (correcting the "bad image" of the Syrian regime on Syrian state television); Rafa Delfin, Fraud alert: Miss Universal Peace and Humanity Organization, CRITICALBEAUTY.COM (Dec. 16, 2014, 8:15 p.m.), http://www.criticalbeauty.com/2014/12/fraud-alert-miss-universal-peace-and.html; see also Mazin Sidahmed, Fake group issuing diplomatic passports, THE DAILY STAR (Feb. 24, 2015, 12:10 AM), http://www.dailystar.com.lb/News/Lebanon-News/2015/Feb-24/288519-fake-groupissuing-diplomatic-passports.ashx (exposing fraudulent beauty pageant and allegations concerning the issuing of fake diplomatic passports); see also Eminent Persons Council, INTERNATIONAL HUMAN RIGHTS COMMISSION http://www.ihrchq.org/life-members/epc.php. 
states as a tool for reinforcing their own policy positions, while reflecting many of the foreseeable shortcomings that flow from failure to comport with recognized international standards, including, ineffectiveness, "majoritarian tendencies," insufficient inclusivity, and "other gaps in normative coverage and practical implementation." 172 As Heyns and Killander aptly sum up, "the question has to be asked whether there are indications that regional human rights mechanisms with certain features rather than others will lean more to the side of being 'protectors' or "pretenders." " 173 The IPHRC is not merely leaning to this latter side, but has firmly entrenched its roots therein. And yet, this reality has not prevented the UN General Assembly, as part of its resolution addressing UN-OIC cooperation, from inviting "increased cooperation and exchanges" 174 between the IPHRC and the OHCHR, and as a consequence, creating additional spaces for the OIC to insert its corrosive take on equality and nondiscrimination into UN human rights efforts.

\section{Plan into ACtion: Recent Manifestations of the OIC'S VISION FOR EQUALITY AND NONDISCRIMINATION}

The previous sections sketched the OIC's early engagement with international human rights as well as more recent efforts to frame an Islamic response to the elaboration of these norms within the international system. Arguably, much of the impetus for the CDHRI, the revised 2008 Charter and the IPHRC flowed from recognition that, since the OIC's debut in the early 1970s, human rights have come to occupy an increasingly significant and strategic arena for international engagement, ${ }^{175}$ and that on this front, the organization lacked a coherent and formal collective policy with which it could engage. ${ }^{176}$

${ }^{172}$ Lyal S. Sunga, Head, Rule of Law Program, Improving Coordination Among NHRIs on Discrimination: Considerations and Recommendations from a Comparative Perspective, 7th session of the Ad Hoc Committee on the Elaboration of Complementary Standards (Jul. 21, 2015), http://www.ohchr.org/Documents/Issues/Elaborationstandards/Session7/LyalSunga.pdf.

${ }^{173}$ Heyns \& Killander, supra note 170, at 530.

${ }^{174}$ G.A. Res. 67/264, U.N. Doc. A/RES/67/264, at II 7 (Aug. 16, 2013).

175 This is true for wielding human rights both as a sword, i.e. leveling allegations of rights violations against other non-OIC states, and as a shield, i.e. arguing that a rights violation directed at an OIC member state is unjustified based on being either overbroad or not universally recognized.

${ }^{176}$ For example, the preamble of OIC Resolution 40/21-P On the Cairo Declaration on Human Rights in Islam "Recogniz[ed] the utmost importance of the issue of human rights in international relations and in particular in relations among the OIC Member States, resulting 
Arguably, being perceived as accepting the validity of human rights norms - even if in rhetoric only-better positions a state to exert its views on the international debate over the substance of these rights. Yet, no matter how laudable the OIC's apparent willingness to recognize an increasingly rights-centric zeitgeist, the foundation for its actual engagement rests squarely on rejection of the universality principle undergirding the entire international human rights framework. Indeed, the primary function of the OIC's approach to rights engagement is premised on advocating and implementing an alternate vision that upends universality in favor of "religious, social, and cultural idiosyncrasies." 177

OIC Secretary General Madani's statement to the opening of the IPHRC's Fourth Session embodies this approach. According to Madani, the "OIC takes pride in the fact that Islam was the first religion that laid down universal fundamental rights for humanity, which are to be observed and respected in all circumstances. Most OIC countries have, therefore, willingly adopted and implemented international human rights norms." 178 Yet at the same time, the Secretary General cautioned, "there are a number of issues that go beyond the normal scope of human rights and clash with Islamic teachings." ${ }^{179}$ In his assessment, these issues arise in the contexts of gender equality, freedom of expression, and domestic application and enforcement of human rights norms. ${ }^{180}$

The Secretary General's framing confirms that the OIC recognizes the centrality of human rights norms, even possibly their universality. This recognition, however, is conditioned on one overarching limitation: if a recognized or asserted right does not comport with the OIC's unspecified understanding of Islam, it falls outside the "normal scope" of universal human rights and presumably is not entitled

from the current developments and interactions in the international arena" and expressed awareness "of the direct implications of this matter on the speedy achievement of development, progress and stability in various economic, social and political fields." Org. of Islamic Cooperation [OIC], Res. 40/21-P, Cairo Declaration on Human Rights in Islam, preamble (Apr. 25-29, 1993).

${ }^{177}$ OIC Res. 1/41-LEG, supra note 90, at art. 4.

${ }^{178}$ Madani, supra note 59.

179 Id.

${ }^{180}$ Id. Puzzlingly, the secretary general omits reference to the right of freedom of thought, conscience and religion or belief as an area where the OIC diverges from the "normal scope" of IHRL. See Blitt, supra note 15, at 155 (arguing "A closer look at the OIC's advocacy favoring a ban on defamation of religion reveals an approach that embodies not one but several anticonstitutional ideas that operate to foreclose the principles of nondiscrimination and equality and undercut universal rights to freedom of expression and freedom of religion or belief."). 
to protection. In practice, discounting rights on this vague basis has the effect of front-ending protection of religious belief at the expense of upholding international law. This approach not only risks exposing potentially vulnerable individuals and groups to harm, but it facilitates that harm by enabling governments to circumvent even the need to justify policies and practices that violate the right at issue.

To better understand how deleterious this approach can be to individual rights and to the overall stability and universality of the international human rights framework, it is useful to consider it in the context of actual practice. Accordingly, the following section explores the OIC's position on "gender equality" - one area highlighted by the OIC as going "beyond the normal scope of human rights and clash[ing] with Islamic teachings" "181 - to illustrate how the organization's framing of equality and nondiscrimination undermines protection for all human beings and risks attenuating the promise of the UDHR and related international norms. Given that the IPHRC reflects the OIC's most recent and high profile effort to engage with the substance of human rights, its endeavors will also be considered alongside those of the OIC to help gauge the extent to which it may or may not be incubating or encouraging an alternate interpretation of equality.

\section{A. WOMEN'S RIGHTS}

Madani's remarks to the IPHRC appear to indicate that the OIC's sole concern regarding gender equality flows from the perception that "Western countries push for the term Gender [to go] beyond the normal definition of men and woman into the direction of how one perceives him/herself rather than his/her actual physical appearance." 182 In reality, this framing conceals a broader OIC disagreement that encompasses the scope and substance of women's rights as well. Therefore, before engaging with the question of equality as it relates to gender identity and sexual orientation, ${ }^{183}$ it is critical to take stock of the

\footnotetext{
${ }^{181}$ Madani, supra note 59.

${ }^{182} I d$.

${ }^{183}$ The Yogyakarta Principles provide helpful definitions here: "Gender identity is understood to refer to each person's deeply felt internal and individual experience of gender, which may or may not correspond with the sex assigned at birth, including the personal sense of the body... and other expressions of gender, including dress, speech and mannerisms." "Sexual orientation is understood to refer to each person's capacity for profound emotional, affectional and sexual attraction to, and intimate and sexual relations with, individuals of a different gender or the same gender or more than one gender." THE YogYAKARTA PRINCIPLES: PRINCIPLES ON
} 
OIC's unease with the concept of women's rights and consider how it conflicts with international protection of equality and nondiscrimination.

Recent data relating to the status of women in OIC states provides a helpful starting point for assessing the OIC's approach to women's rights and framing the scope of the problem. According to a 2015 report released by the Statistical, Economic and Social Research and Training Centre for Islamic Countries (SESRIC), ${ }^{184}$ "the average gender equality index scores in 2013 reveal that the OIC group has the lowest gender equality index score compared with all three country groups (non-OIC developing, developed and world)." ${ }^{185}$ In other words, the OIC as a collective of states ranks lowest in terms of gender equality. ${ }^{186}$ Based on SESRIC's findings, one of the principal reasons for this inequality is limited participation of women in the decision-making process. For example, globally, women on average account for 28.8 percent of legislators, senior officials, and managers. ${ }^{187}$ This representation level actually increases to 33.1 percent when considering only non-OIC developing countries. ${ }^{188}$ In contrast, when singling out OIC states, representation of women within this professional class plummets to 15.6 percent, or less than half of the level achieved by the rest of the developing world. ${ }^{189}$

Other statistics are equally disconcerting. OIC states maintained the lowest labor force participation rate (LFPR) for women in the world, trailing the global average by nearly 15 percent. ${ }^{190}$ Further, while literacy rates in OIC states overall are "not impressive," according to SESRIC, when viewed "from a gender disparity perspective" they show "even a less optimistic picture," with only 64.2 percent of women able to read

\footnotetext{
THE APPlication of International Human Rights LAW IN RElation to SEXual $\begin{array}{llllll}\text { ORIENTATION } & \text { AND } & \text { GENDER } & \text { IDENTITY } & 6 & \text { (Mar. }\end{array}$ http://www.yogyakartaprinciples.org/wp/wp-content/uploads/2016/08/principles_en.pdf.

${ }^{184}$ SESRIC is a subsidiary body of the OIC.

185 According to SESRIC, the gender equality index is a "globally recognized comprehensive [index]. . of the CIVICUS Foundation." Statistical, Econ. \& Soc. Research \& Training Ctr. for Islamic Countries [SESRIC], Org. of Islamic Cooperation [OIC], State of Gender and Family Well-Being in OIC Member Countries 3 (2015), http://www.sesrtcic.org/publicationsdetail.php?id=339.

186 Id.

${ }^{187}$ Id. at $41-42$.

${ }^{188} I d$. at 5.

189 Id.

${ }^{190} I d$. at 32. The LFPR is a "critical indicator used to assess women's participation in economic life." Id. at 31.
} 
and write. ${ }^{191}$ Exacerbating limited education, employment, and advancement prospects, approximately 130,000 women in the OIC states "died from preventable causes related to pregnancy and childbirth in 2013 , corresponding to $44 \%$ of world total maternal deaths," $" 192$ a statistic the OIC Secretary General lamented as "deeply regrettable." 193

\section{OIC Plan of Action for the Advancement of Women (OPAAW)}

To be clear, the OIC is cognizant of these profoundly disturbing development trends. The 2008 OIC Plan of Action for the Advancement of Women (OPAAW) ${ }^{194}$ followed on the heels of the new OIC Charter and marked the first concerted effort by the organization to engage with the issue of discrimination against women. The document's preamble acknowledges, "women today suffer exclusion and marginalization and face difficulties that impede their participation in social life and other areas." 195 It then proceeds to attribute these problems to behaviors that "emanate from non-Islamic norms and practices as well as misunderstanding of religion." 196

At the same time, the OPAAW premises women's rights on a grant from Islam, ${ }^{197}$ qualifies any state party adherence to CEDAW provisions "in line with Islamic values of justice and equality," 198 and reiterates support for drafting the CRWI "in accordance with ... the Cairo Declaration on Human Rights in Islam." 199 The OPAAW further endorses the development of women "based on social justice, distinctive consideration of women, female education, health and promoting economic activities. . guided by the lofty teachings of Islam" and calls for women to "be respected, developed, empowered, considered full

${ }^{191}$ Id. at 10. Secretary General Madani acknowledged this literacy deficit was "significantly regressive". Iyad Ameen Madani, Org. of Islamic Cooperation Sec'y Gen., Statement during debate on "Impact of Women Empowerment on the Sustainable Development of Member States" at the Ninth Regular Session of the IPHRC (May 4, 2016).

192 OIC Doc. OIC/13TH SUMMIT 2016/FC/FINAL, supra note 14, II 150.

${ }^{193}$ Madani, supra note 191.

${ }^{194}$ Second Ministerial Conference on "Women's Role in the Development of OIC Member States," OIC Plan of Action for the Advancement of Women [OPAAW], OIC Doc. OIC/2-WCOD/2008-

${ }^{195} I d$. at II 3 .

${ }^{196}$ Id.

${ }^{197}$ Id. at II 6.

${ }^{198} \mathrm{Id}$. at II 8.

${ }^{199}$ Id. at art. I(1). 
active participants in social, political, cultural and economic spheres, enjoying their rights and fulfilling their duties. ${ }^{200}$

In sum, while the OPAAW does recognize the challenge discriminatory customs and traditions may pose in achieving women's equality, the Plan's very definition of equality is made contingent on undefined religious norms that emphasize a separate role for women that is distinct and different from men and that comes with its own set of rights and duties rather than the same rights and duties. Accordingly, the laudable goal of "achieving gender equality and empowerment of women at all levels and all sectors" ${ }^{201}$ must be understood in its peculiar context, namely a vision of equality that perpetuates the problematic formulation of rights set forth under the CDHRI. While this understanding may help to account for why CEDAW has "the largest number of general and specific reservations, based on [Shari'ah] law," 202 the OIC's distinction and separation based on gender nevertheless remains antithetical to the Convention's call for "the full development and advancement of women, for the purpose of guaranteeing them the exercise and enjoyment of human rights and fundamental freedoms on a basis of equality with men." 203

The OIC's effort to establish an action plan for women premised on discriminatory treatment similarly contradicts CEDAW's antidiscrimination safeguards, which require state parties, "to take all appropriate measures, including legislation, to modify or abolish existing laws, regulations, customs and practices which constitute discrimination against women," ${ }^{204}$ including those "based on the idea of the inferiority or the superiority of either of the sexes or on stereotyped roles for men and women." 205 As the UN Working Group on the Issue of Discrimination Against Women in Law and in Practice (UN Working Group on Discrimination Against Women) has summarized:

Several United Nations human rights experts, special procedures mandate holders, treaty bodies and the Secretary-General of the United Nations have established that neither cultural diversity nor freedom of religion may justify discrimination against women.

${ }^{200} I d$. at 2 (emphasis added).

${ }^{201} I d$. at $2-3$.

${ }^{202}$ CISMAS, supra note 2, at 266.

${ }^{203}$ CEDAW, supra note 64, at art. 3.

${ }^{204}$ Id. at art. 2(f).

${ }^{205}$ Human Rights Council, Report of the Working Group on the Issue of Discrimination Against Women in Law and in Practice, II 15, U.N. Doc. A/HRC/29/40, If 15 (Apr. 2, 2015). 
Discriminatory, repressive and violent practices against women should be eliminated, whatever their origins, including those founded in culture or religion. The Working Group is convinced that this opinion is crucial to securing women's enjoyment of their right to equality in all aspects of life. ${ }^{206}$

From the perspective of the UN Working Group on Discrimination Against Women, therefore, the OPAAW would appear to perpetuate the same justifications international human rights law has been tasked with denying. Additional aspects of OPAAW discussed below reinforce the OIC's effort to validate women's inequality on the basis of religious norms.

\section{OIC Organization of Women Development (WDO)}

The OPAAW also calls for establishing a new OIC subsidiary organ to "address the role of women in the development of OIC Member States' societies." 207 To this end, in May 2010 the OIC's Council of Foreign Ministers adopted a statute for the OIC Organization of Women Development (WDO). ${ }^{208}$ Among other things, the WDO is envisioned as overseeing "the development and promotion of the role of women in the OIC Member States ... in line with the principles of the Islamic values," 209 by "implement[ing] the OIC's resolutions and recommendations in the areas of its work." ${ }^{210}$

According to the statute, the WDO's specific objectives include:

1. Highlight[ing] the role of Islam in preserving the rights of the Muslim woman especially at the international fora in which the Organization is involved; ... . [and]

\footnotetext{
${ }^{206}$ Id. at $\mathbb{\text { II }} 17$.

${ }^{207}$ OPAAW, supra note 194 , at 9.

${ }^{208}$ Council of Foreign Ministers, Res. 2/37, On the Establishment of a Specialized Organization for Women Development in OIC Member States, OIC Doc. OIC/CFM-37/2010/ORG/RES/FINAL (May 18-20, 2010).

${ }^{209}$ Organization of Islamic Cooperation [OIC], Statute of the OIC Women Development Organization, OIC Doc. OIC/EGM-2009/DS-WDO/REP/FINAL, at art. 2, http://www.oicoci.org/english/convenion/Statue_of_the_oic_women_development_org_en.pdf [hereinafter WDO Statute]. Of note, the draft statute originally called for these activities to be "in line with the principles of the Islamic Sharia." OIC, Res. 4/36-ORG, On the Establishment of a Specialized Organization for Women Development In OIC Member States, OIC Doc. OIC/CFM36/2009/ORG/RES/FINAL (May 23-25, 2009), at art. 2.

${ }^{210}$ WDO Statute, supra note 209, at art. 3.
} 
8. Activat[ing] the rights of women enshrined in the OIC Charter by working to remove the restrictions that will enable women to participate in community building. ${ }^{211}$

Based on this formulation, if the WDO does in fact materialize, it is quite likely to reflect the OIC's priorities-namely, ensuring Islamic values curtail any undesirable or "abnormal" interpretation of the scope of women's rights - rather than promote universal women's rights equally and without discrimination. It is worth recalling here that the OIC's 2008 Charter had little to offer in support of women's rights. In the first instance, the Charter lumps protection of women's rights together with "children, youth, elderly and people with special needs as well as the preservation of Islamic family values" as the fourteenth of twenty stated organizational objectives. ${ }^{212}$ In addition, the Charter's preamble explicitly rejects the possibility of international human rights norms informing women's rights, and instead determines the OIC will "safeguard and promote the rights of women and their participation in all spheres of life, in accordance with the laws and legislation of Member States." ${ }^{213}$ In other words, invoking the OIC Charter as the touchstone for activating women's rights promises the perpetuation rather than the elimination of gender inequality and discrimination.

Despite the passing of six years and continued OIC calls on member states to act, ${ }^{214}$ the WDO statute remains unratified and the body itself mere illusion. ${ }^{215}$ For the purposes of this article, however, the OPAAW and WDO serve to illustrate a larger fundamental point. That is, the OIC's approach to women's rights remains fixated on entrenching its own particularized understanding of Islamic norms and obstructing the promise of full and equal rights and freedoms for women without distinction of any kind, as set forth under the international human rights

${ }^{211} I d$. at arts. 5(1), (8).

${ }^{212} 2008$ OIC Charter, supra note 6 , at art. 1.

${ }^{213}$ It is difficult to construe this proviso as anything other than a limitation on the applicability of international law in the realm of women's rights. Id. at 2.

${ }^{214}$ For example, the $42^{\text {nd }}$ Session of the Council of Foreign Ministers "Call[ed] on the Member States to sign and ratify the statute of the specialized Organization for Women Development, based in Cairo with the view to operationalize it." OIC Resolution No. 4/42-C On Social and Family Issues, supra note 91, at 9 [ B(14).

${ }^{215}$ The statute requires fifteen ratifications to enter into force. WDO Statute, supra note 209, at art. 12. According to the OIC, "So far, only eighteen (18) Member States signed the Statute and three (3) ratified it." SG Report on Legal Affairs ( $\left.40^{\text {th }} \mathrm{CFM}\right)$, supra note 85 , at II N. Member states that have ratified the WDO statute are: Gabon, Pakistan, and The Gambia. Id. at II Z. States that have signed are: Egypt, Mali, United Arab Emirates, Djibouti, Comoros, Benin, Niger, Mauritania, Indonesia, Libya, Saudi Arabia, Turkey, Guinea, Chad, Kuwait, and Palestine. Id. at II Y. 
framework. This policy is confirmed by the organization's a priori foreclosure of critical debate surrounding the parameters of these freedoms, even within the framework of bona fide Islamic sources. Revealingly, the OIC's Mechanism for Implementation of the OPAAW purports to permit "OIC Member States, Muslim civil society organizations, communities and the media" to encourage and fund public debate on the issue of women's rights, but only when that debate reflects positively on the rights of women in Islam. ${ }^{216}$ It is also reinforced by continued invocation of the CDHRI - at the expense of other international texts ${ }^{217}$ - as a valid departure point for defining the scope of women's rights, and by ongoing calls to adopt the CRWI, ${ }^{218}$ the substance of which likely would only further undermine the universal objective of achieving women's equality in all areas. ${ }^{219}$

\section{IPHRC on Women's Equality}

For its part, the IPHRC has exhibited a steady endorsement of the restrictive approach to women's equality, with little indication of discomfort with the prevailing OIC position. As its departure point, the Commission has adopted the premise that any criticism of the treatment of women under Islamic law is based on misperception or ill-will rather than any possibility of conflict between Islam and universal human rights norms. ${ }^{220}$ To this end, it has "agreed to work closely with the [OIC's] Fiqh Academy in order to correct the misperceptions regarding the rights

${ }^{216}$ Third Ministerial Conference on Women's Role in the Development of OIC Member States, Mechanism for the Implementation of the OPAAW, art. I(14), OIC Doc. OIC/3WCOD/2010/MECH, (Dec. 19-21, 2010). The alternative approaches to Islamic sources Yakin Ertürk alludes to above likely would be foreclosed from such a debate. See U.N. Human Rights Council, supra note 51, at II 40.

${ }^{217}$ In contrast, the OIC is at ease invoking the applicability of international norms for others. For example, calling "upon the international community to shoulder its full responsibility in compelling Israel to abide by the principles of the Universal Declaration on Human Rights. .."; and calling on the government of India to "Ensure the safety and protection of the Muslims and all Islamic Holy Sites throughout India in accordance with its responsibilities and obligations under the Universal Declaration of Human Rights." See Council of Foreign Ministers, Res. 2/41C On Palestinian Cultural Affairs, at II 5, OIC Doc. OIC /CFM-41/2014/CSF /RES/FINAL, (Jun. 18-19, 2014); see also Council of Foreign Ministers, Res. 3/41-C, On Protection of Islamic Holy Places, at II 6(a), OIC Doc. OIC /CFM-41/2014/CSF /RES/FINAL, (Jun. 18-19, 2014).

${ }^{218}$ Council of Foreign Ministers, Res. 4/41-C On Social and Family Issues, at II 10, OIC Doc. OIC/CFM-41/2014/CSF/RES/FINAL, (June 18-19, 2014).

${ }^{219}$ This conclusion derives from the substance of the CRCI and OIC member state standing and open-ended Shari'ah-based reservations to CEDAW.

${ }^{220}$ This mirrors the position espoused by the OIC under the OPAAW. See OPAAW, supra note 196. 
of women and children in Islam, as well as the protection of the family." 221 The Commission has further volunteered to lobby at the UN by "holding seminars and side events" intended to counter what it claims (without substantiating) is "massive propaganda against Islam by certain international NGOs." 222

Other examples of IPHRC's unwavering affirmation of the OIC position abound. In two separate addresses given during the Commission's seventh session, Ambassador Ilham Ibrahim, the IPHRC chair, omitted any mention of women's equality-an especially egregious oversight given that session's theme focused on "the protection of family values." ${ }^{223}$ Furthermore, the IPHRC continues to herald the CDHRI as a legitimate measure for women's equality. ${ }^{224}$ This, despite long-standing concerns surrounding the declaration's compatibility with international human rights norms and the fact that the OIC CFM previously had tasked the Commission "to review [the] OIC Human Rights Declaration against existing universal human rights instruments and make suggestions for its improvement, if and where necessary." 225

One might argue the IPHRC's human rights analysis and activities are more nuanced and may signal a challenge to the OIC's conventional approach. However, any such nuance remains faithful to the organization's overarching modus operandi, namely upholding vague Islamic norms as the first priority, even at the expense of women's equality. For example, alongside its endorsement of the CDHRI, the IPHRC has also affirmed the "United Nations Bill of Rights and other

${ }^{221}$ M. K. Ibrahim, IPHHRC Chairperson, Statement at the Sixth Session of IPHRC, II 3(B)(i) (Nov. 2014), http://www.oiciphrc.org/data/sessions/closing\%20statement\%20of\%20the\%20IPHRC\%20Chair\%206\%20Nov $\%$ 202014.pdf. The International Islamic Fiqh Academy (IIFA) is a subsidiary organ of the OIC created in 1981 and based in Jeddah, Saudi Arabia. It is tasked with studying "contemporary problems from the Sharia point of view and [trying] to find the solutions in conformity with the Sharia through an authentic interpretation of its content." Subsidiary Organs, ORG. OF ISLAMIC COOPERATION http://www.oic-oci.org/oicv3/page/?p_id=64\&p_ref=33\&lan=en\#FIQH (last visited Mar. 17, 2017).

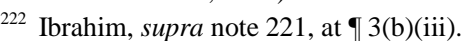

${ }^{223}$ Ilham Ibrahim, IPHRC Chairperson, Statement at the Seventh Session IPHRC 3 (Apr. 21, 2015), http://www.oic-iphrc.org/data/sessions/Statement_by_amb_Ilham_en.pdf.

${ }^{224}$ OIC-IPHRC 9th Session: Outcome Document of Thematic Debate On 'Impact of Women Empowerment On Sustainable Development of Member States', (May 4, 2016).

${ }^{225}$ Council of Foreign Ministers, Res. 1/42-LEGAL, Follow-Up and Coordination of Action in the Field of Human Rights, If 12 (May 27-28, 2015) (At the time of writing, nothing has materialized out of this request). 
international human rights instruments, including the CEDAW."226 Pooling these instruments together may signal a willingness to recognize compatibility between Islamic and international human rights norms. Yet, this compatibility is asserted without substantiation and in the face of member state practice to the contrary. This ongoing tension is readily discernable even within the IPHRC's own policy statements. For example, the Commission boldly asserts the "importance of gender equality and avoiding stereotyped role of women" and the need to address these issues "at all levels through appropriate training and education." 227 At the same time, it perpetuates (in the same statement) the very stereotypes it purports to condemn, for example, by endorsing traditional roles and responsibilities of women within the family as "nutritional gatekeepers, saving stimulators and wellbeing moderators." 228

Although particularly acute in the context of family (discussed separately below), this distorted understanding of women's equality ultimately permeates the IPHRC's work. It is encapsulated in a disingenuous vision that professes to endorse equality while all at once restricting its scope and application. Consider the IPHRC's qualified position "that men and women enjoy equal human dignity and fundamental human rights but have different roles and responsibilities within the family and society, and that Islam nowhere implies superiority or inferiority to either of the sexes." 229 The Commission appears to have satisfied itself that this vague determination represents an authoritative policy statement on women's equality. Women and other concerned observers, however, are left to ponder two critical questions. First, how does the Commission's understanding of "different roles and responsibilities within the family and society" implicate actual equality? Second, what specific religious sources does the Commission rely upon

\footnotetext{
${ }^{226}$ IPHRC $9^{\text {th }}$ Session Outcome Document, supra note 224.

${ }^{227} I d$.

${ }^{228}$ Abdul Wahab, IPHRC Chairperson Statement to Thematic Debate. http://www.oiciphrc.org/data/sessions/Amb\%20Abdulwahab\%20statementt\%20For\%20the\%20thematic\%20de bate\%20on\%20Women\%20Empowerment\%20REVISED.pdf.

${ }^{229}$ Press Release, OIC Independent Permanent Human Rights Commission (IPHRC) Concludes its 6th Regular Session in Jeddah (Nov. 1-6, 2014), http://www.oiciphrc.org/data/sessions/Final\%20Communique\%20of\%20the\%20IPHRC\%206th\%20session\%20 -\%206\%20Nov\%202014.pdf; see also Press Release, IPHRC reaffirmed the importance of family as the natural and fundamental unit of society that is entitled to protection by State and Society, during its thematic debate on "Protection of Family Values" (Apr. 21, 2015), http://www.oic-iphrc.org/en/press_details/?id=84.
} 
in concluding that neither sex is superior according to Islam, and does its interpretation concur with that of OIC member states?

\section{Different "Roles and Responsibilities": A Frontal Challenge to Women's Equality}

In attempting to answer the first question, one might query whether the Commission has in mind the same equality that flows from the different roles and responsibilities foisted on women in the Islamic Republic of Iran. This arrangement has been described elsewhere as being:

[G]rounded in a culture of patriarchy, and reinforced (and ostensibly justified) by a patriarchal interpretation of Islam's holy sources. A cornerstone of the Islamic Republic's gender ideology is the conviction that men and women are fundamentally "different" beings in nature. This conviction is derived from a conservative Islamic world view in which men and women exist, function, and relate to one another only within the limits of a "natural" gender hierarchy. That is, due to God-given differences in terms of both biology and psychology, men and women have different roles and responsibilities in society. In Iran, this has translated into a reality for women in which they occupy a subordinate status to men. ${ }^{230}$

Iran is but one state and surely, its idiosyncratic interpretation of Islamic law does not govern overall OIC policy. This said, even a cursory examination of the CEDAW regime illustrates that many parties seek to maintain similar patriarchal and religion-justified understandings of women's roles and responsibilities that are antithetical to the treaty's objective of eliminating inequality and discrimination. For example, article 16 of CEDAW provides: "States Parties shall take all appropriate measures to eliminate discrimination against women in all matters relating to marriage and family relations and in particular shall ensure, on a basis of equality of men and women...[t]he same rights and responsibilities;" "during marriage and at its dissolution;" "as parents, irrespective of their marital status;" and "with regard to guardianship,

\footnotetext{
${ }^{230}$ Rebecca Barlow \& Shahram Akbarzadeh, Prospects for Feminism in the Islamic Republic of Iran, 30 HuM. RTS Q. 21, 23 (2008) (emphasis added) (concluding that "Iranian women appear to be increasingly disillusioned with religious-oriented feminism as it has proven unable to achieve lasting change... The solution to the plight of Iranian women is no longer seen coming solely or primarily from within Islam, but rather in the separation of the state and its legal codes from strict religious doctrine." Id. at 40).
} 
wardship, trusteeship and adoption of children." ${ }^{231}$ Further, in its General Recommendation 29, the CEDAW Committee clarified the obligation to ensure full equality and nondiscrimination between men and women in the context of personal status matters:

\begin{abstract}
Inequality in the family underlies all other aspects of discrimination against women and is often justified in the name of ideology, tradition and culture. An examination of States parties' reports reveals that in many States, the rights and responsibilities of married partners are governed by civil or common law principles; religious or customary laws and practices; or some combination of such laws and practices; that discriminate against women and do not comply with the principles set out in the Convention. ${ }^{232}$
\end{abstract}

Accordingly, the Committee reiterated its longstanding view that article 16 is a core provision of CEDAW, that "[n] either traditional, religious or cultural practice nor incompatible domestic laws and policies can justify violations of the Convention," and as such, "reservations to article 16, whether lodged for national, traditional, religious or cultural reasons, are incompatible with the Convention and therefore impermissible."233

Despite this clear stance, Article 16 has "the greatest number of reservations, either to the entire provision or to individual subsections" among all CEDAW provisions. In 2009, thirty-four States Parties to CEDAW maintained reservations to all or part of this provision, with more than half of these being OIC members. ${ }^{235}$ By 2016, this number had moved slightly down to thirty states reserving, with OIC members still representing more than half of those reserving states. ${ }^{236}$ Notably, Tunisia and Morocco did withdraw reservations to article 16 in 2011 and 2014 respectively. ${ }^{237}$ While these withdrawals may do away with the states

${ }^{231}$ CEDAW, supra note 64, at art. 16(1)(c), (d), (f) (emphasis added).

${ }^{232}$ Comm. on the Elimination of Discrimination Against Women, General Recommendation on Article 16 of the Convention on the Elimination of All Forms of Discrimination Against Women, U.N. Doc. CEDAW/C/GC/29, II 2 (Oct. 30, 2013) (emphasis added).

${ }^{233}$ Id. at II 54; Comm. on the Elimination of Discrimination Against Women, Rep. of Its Nineteenth Session, supra note 68, at II 17.

${ }^{234}$ Freeman, supra note 66, at 6.

${ }^{235} I d$.

${ }^{236}$ Data produced by updating Freeman's 2009 survey of CEDAW reservations using current information from the UN Treaty Collection database. Depositary Notifications (CNs) by the Secretary-General, U.N. TREATY COLLECTION, https://treaties.un.org/Pages/Content.aspx?path=DB/CNs/pageIntro_en.xml (last visited Mar. 17, 2017).

${ }^{237}$ CEDAW, Morocco: Partial Withdrawal of Reservations Made Upon Accession, U.N. Doc. C.N.176.2011.TREATIES-2 (Apr. 18, 2011) (Depositary Notification); see also CEDAW, Tunisia: Withdrawal of the Declaration With Regard To Article 15(4) and of the Reservations To 
parties' explicit rejection of women's equality, the move is necessarily tempered by the fact that both states continue to maintain a general catchall declaration subjecting CEDAW implementation to compatibility with unspecified provisions of Islam. ${ }^{238}$ To drive home this important point, it bears recalling that Jordan, a more "moderate" OIC state than Iran, maintains that it must preserve its specific reservations ${ }^{239}$ to CEDAW article $16(1)(\mathrm{c}),(\mathrm{d})$ and $(\mathrm{g})$ precisely because " $[\mathrm{u}]$ nlike other Islamic countries, Jordan had not entered a blanket reservation to all articles that [run] counter to [Shari'ah] law." ${ }^{240}$

The example of Jordan's reservations to CEDAW is particularly instructive in unpacking the IPHRC's position on gender equality for two reasons. First, Jordan is not Iran; and yet, its approach to women's equality still seeks to uphold different roles and responsibilities that result in inequality and discrimination. ${ }^{241}$ This position is so fundamentally entrenched that Jordan's recent Royal Commission on the amendment of the Constitution "found that there was no need" to add sex or gender as a protected class under the Constitution's nondiscrimination clause, because it already "provides that Jordanians are equal before the law and that no distinction shall be made among them in respect of rights

Articles 9(2), 16 (C), (D), (F), (G), (H) and 29(1) Made Upon Ratification, U.N. Doc. C.N.220.2014.TREATIES-IV.8 (Apr. 23, 2014) (Depositary Notification).

${ }^{238}$ Morocco's declaration expresses its readiness to apply the provisions of article 2 (addressing discrimination) provided, inter alia, "They do not conflict with the provisions of the Islamic Shariah." See C.N.176.2011.TREATIES-2, supra note 237. Tunisia's declaration similarly provides "it shall not take any organizational or legislative decision in conformity with the requirements of this Convention where such a decision would conflict with the provisions of chapter I of the Tunisian Constitution." See Id. Among other things, Chapter 1 of the Tunisian constitution declares Islam the state religion and establishes the state as "the guardian of religion." CONSTITUTION OF THE REPUBLIC OF TUNISIA 2014, arts. 1, 6, https://www.constituteproject.org/constitution/Tunisia_2014.pdf (UNDP \& Int'l IDEA trans.) According to Human Rights Watch, "Although Tunisia has one of the most progressive personal status codes in the region, the code still contains discriminatory provisions." Tunisia: Landmark Action on Women's Rights, HUMAN Rights WATCH (Apr. 30, 2014, 11:55 p.m.), https://www.hrw.org/news/2014/04/30/tunisia-landmark-action-womens-rights.

239 The effect of a "reservation" or "declaration" hinges not upon the label assigned by the invoking state, but rather upon the substance of the statement conveyed. Under the Vienna Convention on the Law of Treaties, a reservation "means a unilateral statement, however phrased or named, made by a State...whereby it purports to exclude or to modify the legal effect of certain provisions of [a] treaty. .." Vienna Convention on the Law of Treaties, art. 2(1)(d), Jan. 27, 1980, 1155 U.N.T.S 331 (emphasis added).

${ }^{240}$ Comm. on the Elimination of All Forms of Discrimination Against Women [CEDAW], Summary Record of the 1033rd Meeting of Its Fifty-First Session, 4, U.N. Doc. CEDAW/C/SR.1033 (Mar. 13, 2012).

${ }^{241}$ CEDAW, Concluding Observations of the Committee on the Elimination of Discrimination Against Women: Jordan, UN Doc. CEDAW/C/JOR/CO/5 (Mar. 23, 2012). 
and duties regardless of their race, language or religion." ${ }^{242}$ The takeaway from this reasoning is simple; upholding a constitutional allowance for different roles and responsibilities presumably excuses any discrimination or inequality that may flow from such differential treatment.

\title{
5. Shari'ah and Women's Equality
}

The other reason Jordan is instructive relates to the second question posed above, namely, on what basis does the Commission conclude that neither sex is superior according to Islam and to what extent does this position concur with the actual practice of OIC member states. For Jordan, the government's underlying justification for maintaining different gender roles and responsibilities flows from an Islamic imperative. As the government explained to the CEDAW Committee in 2006:

\begin{abstract}
Jordan maintains its reservation to. . .article $16[\mathrm{c}]$ of the Convention on the grounds that it is incompatible with the Shari'a. Under Jordanian law, marriage is not based on equality of rights and duties for husband and wife, but on reciprocity, i.e. rights for the wife with corresponding duties for the husband, and rights for the husband with corresponding duties for the wife. It follows that the concept of equality between spouses cannot be made to fit into the existing legal system. ${ }^{243}$
\end{abstract}

Jordan has continued to assert this position, even in the face of repeated expressions of concern by the CEDAW Committee. ${ }^{244}$ In 2010, it reported to the Committee that "despite demands from many women's organizations, Jordan maintains its reservation to [article 16] because it is

${ }^{242}$ CEDAW, Concluding Observations on the Fifth Periodic Report of Jordan, Information Provided by Jordan in Follow-up to the Concluding Observations, UN Doc. CEDAW/C/JOR/CO/5/Add.1, at 1 (Dec. 2, 2014) (emphasis added). Article 6(i) of the Kingdom's constitution states: "Jordanians shall be equal before the law. There shall be no discrimination between them as regards to their rights and duties on grounds of race, language or religion." THE CONSTITUTION OF THE HASHEMITE KINGDOM OF JORDAN, Jan. 1, 1952, art. 6, http://www.constitutionnet.org/files/2011_constitution_-_jordan_english_final.pdf (Int'l IDEA trans., 2012).

${ }^{243}$ CEDAW, Consideration of Reports Submitted by States Parties Under Article 18 of the Convention on the Elimination of All Forms of Discrimination Against Women, Combined Third and Fourth Reports of States Parties: Jordan, II 248, U.N. Doc. CEDAW/C/JOR/3-4 (Mar. 10, 2006) (emphasis added).

${ }^{244}$ See CEDAW, Concluding Comments of the Committee on the Elimination of Discrimination Against Women: Jordan, If 11, U.N. Doc. CEDAW/C/JOR/CO/4, (Aug. 10, 2007). 
incompatible with the provisions of Islamic law, the Shari'a . . . Over and above this legal reason . . . we may add the fact that husband and wife have different responsibilities in the framework of a single family." 245 Similarly, Jordan's sixth periodic report, filed in 2015, asserted that the CEDAW Committee's recommendations to withdraw article 16 reservations "failed to meet with Jordan's approval. . .on the grounds of their incompatibility with Islamic Shariah." ${ }^{246}$

Ultimately, Jordan's steadfast defense of different gender roles and responsibilities - as well as its justification that such differentiation is dictated by Shari'ah-is not the outlier view. The disproportionately high number of OIC states taking reservations to CEDAW and the outcomes of their CEDAW reviews testify to this reality. ${ }^{247}$ If the IPHRC's vague generalizations about Shari'ah compatibility with universal human rights mirror this more "moderate" stance, then its position on women's rights necessarily translates into a vision that entrenches systemic inequality and discrimination by accommodating, among other things, the practice of polygamy (for men only), ${ }^{248}$ restrictions on a woman's right to work and to choose a spouse freely, ${ }^{249}$

${ }^{245}$ CEDAW, Consideration of Reports Submitted by States Parties Under Article 18 of the Convention on the Elimination of All Forms of Discrimination Against Women, Fifth Periodic Report of States Parties: Jordan, If 302, UN Doc. CEDAW/C/JOR/5 (Sept. 24, 2010) (emphasis added) [hereinafter CEDAW, Fifth Periodic Report of States Parties: Jordan].

${ }^{246}$ CEDAW, Consideration of Reports Submitted by States Parties Under Article 18 of the Convention, Sixth Periodic Report of States Parties Due in 2016: Jordan, II 108, U.N. Doc. CEDAW/C/JOR/6 (June 25, 2015). According to the government, "the Jordan Islamic Scholars League sent a letter to the speaker of the House of Representatives calling upon the house not to approve lifting the reservations to the Convention, on the grounds that they violate Islamic Shariah. Accordingly, the issue of lifting the reservations has to be dealt with very sensitively and gradually, in a manner that balances the promotion of women's human rights with the obligation to reject whatever contradicts the provisions of Islamic Shariah." Id. (emphasis added).

${ }^{247}$ See e.g., CEDAW, Concluding Observations on the Combined Fourth and Fifth Periodic Reports of Lebanon, U.N. Doc. CEDAW/C/LBN/CO/4-5 (Nov. 24, 2015); CEDAW, Concluding Observations on the Combined Fourth and Fifth Periodic Reports of the Gambia, U.N. Doc. CEDAW/C/GMB/CO/4-5 (July 28, 2015); CEDAW, Concluding Observations on the Fourth Periodic Report of Pakistan, U.N. Doc. CEDAW/C/PAK/CO/4 (Mar. 27, 2013); CEDAW, Concluding Observations on the Combined Initial and Second Periodic Reports of Afghanistan, U.N. Doc. CEDAW/C/AFG/CO/1-2 (Jul. 30, 2013); CEDAW, Concluding Observations of the Committee on the Elimination of Discrimination Against Women on the Initial Report of the United Arab Emirates, U.N. Doc. CEDAW/C/ARE/CO/1 (Feb. 5, 2010).

${ }^{248}$ CEDAW, Combined $3^{\text {rd }}$ and $4^{\text {th }}$ Reports of States Parties: Jordan, supra note 243, If 246.

${ }^{249}$ CEDAW, Rep. of Jordan on Its Fifty-first Session, Summary Record (partial) of the 1034th meeting, If 42, U.N. Doc. CEDAW/C/SR.1034 (Mar. 22, 2012); see also CEDAW, Combined $3^{\text {rd }}$ and $4^{\text {th }}$ Reports of States Parties: Jordan, supra note 243, If 245; see also CEDAW, Concluding Observations of the Committee on the Elimination of Discrimination Against Women: Jordan, supra note 241, at If 49 ("The Committee notes with concern the continued application of the 
discriminatory gender-based inheritance rules, ${ }^{250}$ and the reinforcement of "traditional images of women's roles and responsibilities in school books and curricula that perpetuate girls' and women's disadvantaged status." ${ }^{251}$

Against this record of practice-specifically OIC states' interpretation and application of Shari'ah law-the IPHRC's claim that "discriminatory practices compromising the rights of women should not be attributed to Islam" simply cannot be reconciled without concrete evidence to the contrary. At least for the time being, therefore, the IPHRC has fallen dramatically short. Indeed, its vague assertions about Islam appear to have been reached without any meaningful effort at analysis or substantiation, nor any comprehensive scrutiny of the deleterious OIC member state policies impacting women's equality and actively being justified on the basis of Shari' ah. ${ }^{252}$

The IPHRC might be tempted to explain all of this inconsistency away by asserting, like the Jordanian government, that "the provisions of Islamic law . . . contain a positive discrimination in favour of the woman," ${ }^{253}$ and that, accordingly, the imposition of different roles and responsibilities is premised on some form of affirmative action intended to protect women rather than perpetuate their disadvantage. Such a framing would not be a leap. For example, the 2004 Arab Charter on Human Rights provides, "men and women are equal in respect of human dignity, rights and obligations within the framework of the positive discrimination established in favour of women by the Islamic Shari'ah." ${ }^{254}$ Yet, the UN High Commissioner for Human Rights has rejected such a formulation as being "incompatib[le]. . .with international

discriminatory provisions contained in the State party's Personal Status Act, in particular the permissibility of polygamy, the requirement of walis (guardians) for women for the marriage notwithstanding the woman's consent, and the restrictions on women's right to work and to divorce.").

${ }^{250}$ CEDAW, Fifth Periodic Report of States Parties: Jordan, supra note 245, at II 315.

${ }^{251}$ UN Doc. CEDAW/C/JOR/CO/5, supra note 241, at II 35.

${ }^{252}$ As of this writing, the IPHRC has yet to make publicly available any detailed analysis on women's rights under Islam. In 2016, the IPHRC announced that it "discussed and adopted" a study on the subject of "Women and Men's inheritance in Islamic Sharia" produced by one of its subcommittees. Press Release, Indep. Permanent Human Rights Comm'n., OIC Independent Permanent Human Rights Commission concludes its 9th Regular Session in Jeddah (May 5, 2016),

${ }^{253}$ CEDAW, Fifth Periodic Report of States Parties: Jordan, supra note 245, at II 305.

254 Arab Charter on Human Rights, League of Arab States, art. 3(3), May 22, 2004 (entered into force March 15, 2008), reprinted in 12 INT’L HUM. RTS. REP. 893 (2005). 
norms and standards." ${ }^{255}$ As long as the IPHRC fails to muster some tangible, detailed, and authoritative indication that OIC member states have somehow consistently misinterpreted or misapplied Islamic law, any approach to equality qualified by an effort to legitimate "different roles and responsibilities" and coupled with vague assurances that "neither sex is superior" must be rejected as contrary to IHRL. To recall the UN Working Group on Discrimination Against Women, "neither cultural diversity nor freedom of religion may justify discrimination against women. Discriminatory, repressive and violent practices against women should be eliminated, whatever their origins, including those founded in culture or religion." 256

\section{B. PROTECTION OF FAMILY VALUES: NEXUS FOR DisCRIMINATION AgAinst WOMEN, ON THE BASIS OF SEXUAL ORIENTATION AND GENDER IDENTITY, AND AGAINST OTHERS}

As observed above, the OIC's endorsement of different roles and responsibilities for men and women operates to significantly undermine gender equality and facilitate the perpetuation of discriminatory practices directed against women. The necessity for these unequal arrangements, in the OIC's view, flows from Islamic religious imperatives. These same imperatives similarly inform the organization's broader concern for preserving its particular vision of "Islamic family values" 257 in the face of perceived "ethical and intellectual challenges threatening [the Islamic family's] identity and existence." 258 The CDHRI encapsulates this vision by resolving that marriage is a necessary precursor to the formation of family and - in contravention of the UDHR - by enabling states to restrict the right to marriage on the basis of religion. ${ }^{259}$ Secretary General

${ }^{255}$ Press Release, UN Office of High Comm'r Human Rights, Statement by UN High Comm'r For Human Rights on the Entry Into Force of the Arab Charter On Human Rights (Jan. 30, 2008), https://web.archive.org/web/20130116101635/http://www.unhchr.ch/huricane/huricane.nsf/view 01/6C211162E43235FAC12573E00056E19D?opendocument.

${ }^{256}$ UN Doc. A/HRC/29/40, supra note 205, at II 205.

${ }^{257} 2008$ OIC Charter, supra note 6, at art. 1(14); see also OIC, 2025 Program of Action, II 48, OIC Doc. OIC/SUM-13/2016/POA-Final.

${ }^{258}$ OIC Resolution No. 4/42-C On Social and Family Issues, supra note 91, at preamble.

259 The CDHRI provides: "The family is the foundation of society, and marriage is the basis of its formation. Men and women have the right to marriage, and no restrictions stemming from race, colour or nationality shall prevent them from enjoying this right." CDHRI, supra note 32, at art. 5(a). In contrast, the UDHR states: "Men and women of full age, without any limitation due to race, nationality or religion, have the right to marry and to found a family. They are entitled to 
Madani likewise has asserted that protection of Islamic family values is of "utmost importance" to the OIC, and has urged the organization's institutions to incorporate an "Islamic perspective" in interrelated fields with a view to projecting unified OIC views and positions. ${ }^{260}$

The OIC's advocacy of an Islamic religious perspective in the family context presents an expanded challenge to safeguarding women's equality and nondiscrimination on the international level. As the UN Working Group on Discrimination Against Women has observed:

While gender stereotypes pervade all aspects of human existence, women's rights are at particular risk in the family, which is a locus for the perpetuation of traditional values. The family is a product of patriarchal culture and a vital institution for upholding the patriarchy. . .women's equal rights in the family are closely linked to their rights in all areas of life, including public and political life and social, economic and cultural life. ${ }^{261}$

In addition to triggering further restrictions on women's rights, including limiting their sexual and reproductive health, the push to protect Islamic family values also subverts the rights of others, including children, refugees, ${ }^{262}$ and LGBTI individuals. Indeed, as demonstrated below, in

equal rights as to marriage, during marriage and at its dissolution." UDHR, supra note 16, at art. 16(1).

${ }^{260}$ Press Release, Indep. Permanent Human Rights Comm'n., OIC Independent Permanent Human Rights Commission (IPHRC) concludes its Seventh Regular Session in Jeddah held from 19-23 April 2015 (Apr. 23, 2015), http://www.oic-iphrc.org/en/press_details/?id=78. The IPHRC's chairperson previously affirmed the Commission would work closely with the OIC's Fiqh Academy "to correct the misperceptions regarding the rights of women and children in Islam, as well as the protection of the family." Ibrahim, Statement at the Sixth Session of IPHRC, supra note 221 , at $\llbracket$ 3(B)(i).

${ }^{261}$ U.N. Doc. A/HRC/29/40, supra note 205, at II 22.

${ }^{262}$ A detailed treatment of the potentially deleterious impact Islamic family values may have on child and refugee rights must be reserved for another occasion due to space constraints. Children's rights are, however, briefly noted below in the context of sexual and reproductive rights. It also bears noting that the OHCHR has recognized that "States' responsibility to protect individuals from discrimination extends to the family sphere, where rejection and discriminatory treatment of and violence against LGBT and intersex family members [including children] can have serious, negative consequences for the enjoyment of human rights." OHCHR, Report on Discrimination and Violence Against Individuals Based on their Sexual Orientation and Gender Identity, at II 66, U.N. Doc. A/HRC/29/23, (May 4, 2015). Similarly, what treatment would await a "non-traditional" refugee family seeking protection in an OIC member state, given the CDHRI's provision that "The country of refuge shall ensure [asylum] protection until he reaches safety, unless asylum is motivated by an act which Shari'ah regards as a crime"? CDHRI, supra note 32, at art. 12 (emphasis added). Even without running afoul of Shari'ah law, the CRCI opens the door to discrimination against refugee children by requiring only that parties ensure "as much as possible, that refugee children. . . enjoy the rights provided." CRCI, supra note 75, at art. 21 (emphasis added). This approach stands in sharp contrast to the equal protection afforded refugee children under the UNCRC: "States Parties shall take appropriate measures to 
seeking to uphold its narrow vision of family, the OIC has emerged as one of the staunchest opponents of applying equality and nondiscrimination protections on the basis of SOGI.

\section{Sexual and Reproductive Health}

According to the CEDAW committee, the right to sexual and reproductive health ${ }^{263}$ includes "the right to make free and responsible decisions and choices, free of violence, coercion and discrimination, regarding matters concerning one's body and sexual and reproductive health." ${ }^{264}$ Like other rights, sexual and reproductive health operates interdependently with other provisions of CEDAW. For example, when combined with the right to education and the right to nondiscrimination and equality between men and women, the right to sexual and reproductive health also "entails a right to education on sexuality and reproduction that is comprehensive, non-discriminatory, evidence-based, scientifically accurate and age appropriate." ${ }^{265}$ The right to sexual and reproductive health "is also indivisible from and interdependent with other human rights" enshrined elsewhere under international law. ${ }^{266}$ For example, "denial of abortion often leads to maternal mortality and morbidity, which in turn constitutes a violation of the right to life or security, and in certain circumstances can amount to torture or cruel, inhuman or degrading treatment." 267

ensure that a child who is seeking refugee status or who is considered a refugee... shall. . receive appropriate protection and humanitarian assistance in the enjoyment of applicable rights set forth in the present Convention and in other international human rights or humanitarian instruments." UNCRC, supra note 76, at art. 22(1). Considering the IPHRC's approach to sexual orientation and protection of the family, its call to "find ways and means to effectivily [sic] protect the family and family integration in conflict and post-confict [sic] situations as well as other emergencies and situations such as migrant and refugee families" appears destined to perpetuate and condone discriminatory outcomes in the context of refugee rights. Press Release, IPHRC Thematic Debate on "Protection of Family Values", supra note 229.

263 This right "is an integral part of the right to health enshrined in article 12 of the International Covenant on Economic, Social and Cultural Rights." Econ. \& Soc. Council, Comm. on Econ., Soc., \& Cultural Rights, General Comment No. 22 (2016) on the Right to Sexual and Reproductive Health (Article 12 of the International Covenant on Economic, Social and Cultural Rights), U.N. Doc. E/C.12/GC/22, at I[ 1 (May 2, 2016).

${ }^{264}$ Id. at $1[5$.

${ }^{265}$ Id. at II 9.

${ }^{266} \mathrm{Id}$. at $\mathbb{I} 10$.

${ }^{267}$ Id. 
The CEDAW Committee has similarly concluded that respect for nondiscrimination in the context of the right to sexual and reproductive health encompasses "the right of all persons, including lesbian, gay, bisexual, transgender and intersex persons, to be fully respected for their sexual orientation, gender identity and intersex status." 268 Here, the Committee further cautioned that LGBTI and other vulnerable individuals and groups risk being "disproportionately affected by intersectional discrimination in the context of sexual and reproductive health." ${ }^{269}$ As such, the state maintains an obligation to ensure that its laws and policies effectively "prevent and eliminate discrimination, stigmatization and negative stereotyping that hinder access to sexual and reproductive health." ${ }^{270}$ Moreover, any "[m]easures to guarantee nondiscrimination and substantive equality should be [designed to] overcome the often exacerbated impact that intersectional discrimination has on the realization of the right to sexual and reproductive health."271

The example of Jordan is again helpful here for illustrating the chasm between the CEDAW Committee and the OIC concerning the right to sexual and reproductive health. From Jordan's convoluted perspective,

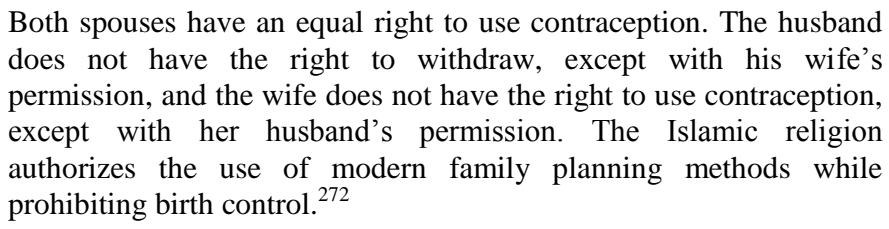

Reconciling this position with CEDAW's fundamental guarantee that a woman has "the right to make free and responsible decisions and choices" ${ }^{273}$ with respect to her body and sexual and reproductive health would appear difficult at best.

For its part, the IPHRC insists only a husband and wife are capable of achieving "a healthy and stable family," and that the enjoyment of basic rights within the family unit must be premised on the notions of mutual support and gender complementarity "enshrined in

\footnotetext{
${ }^{268} I d$. at $\mathbb{I} 23$.

${ }^{269}$ Id. at $\mathbb{\text { II }} 30$.

${ }^{270} I d$. at $\mathbb{I I} 31$.

${ }^{271} I d$. at II 30.

${ }^{272}$ CEDAW, Fifth Periodic Report of States Parties: Jordan, supra note 245, at If 308.

${ }^{273}$ Econ. \& Soc. Council, supra note 263, at II 5.
} 
Islamic values." ${ }^{274}$ Here too, the Commission has used its platform to validate the OIC's stance on sexual and reproductive health rights. Mirroring the OIC CFM, the IPHRC has framed the CEDAW Committee's observations above as a threat to the Islamic conception of human rights. During an IPHRC thematic debate on the "Protection of Family Values," the Commission "condemned the practice of promoting divisive and non-universal rights of comprehensive sexuality education to children, which include morally unacceptable concepts, behaviours and practices." ${ }^{275}$ Further, it rejected official UN-disseminated publications that reference comprehensive sex education for children and "the so-called notion of sexual orientation," branding them "disturbing and morally unacceptable," "potentially harmful to the very institution of family," and "undermining the spirit of. . universally accepted human rights values, norms and instruments." 276 In concluding its debate, the IPHRC urged all stakeholders, including NGOs and NHRIs, "to put the family at the core of their agendas" and avoid "misconceptions and controversies" which contradict IPHRC's vision of family values. ${ }^{277}$

The IPHRC's rejection of sex education programming content and its framing of such programs as a threat to the institution of family makes clear that the OIC's efforts to protect the family go beyond controlling women and restricting their equality. Rather, the quest to safeguard Islamic family values also entails undercutting the rights of children as well as a rejection of what the Commission derisively terms "so-called" sexual orientation, effectively dismissing out of hand the application of equality and nondiscrimination principles to the LGBTI community. ${ }^{278}$

\section{Protecting an "Ideal Family" Demands Religious Conformity, Not Recognition of Family Diversity}

The OIC's justification for discriminating on the basis of SOGI is grounded in religion. Making this position plain, the IPHRC ended its 7th session in 2015 concluding that "the growing trend of confusing the definition of family with new and controversial notions of LGBT

\footnotetext{
${ }^{274}$ IPHRC Thematic Debate on "Protection of Family Values", supra note 229.

${ }^{275} I d$.

${ }^{276} I d$.

${ }^{277} I d$.

${ }^{278}$ The OIC's perspective on LGBTI rights in the context of equality and nondiscrimination is discussed in a forthcoming article.
} 
families that were neither universal nor recognized by international human rights standards" 279 was diametrically opposed to the Koran's concept of a "Good society." 280 This good society, in the IPHRC's words, can "only be achieved through the marriage between man and woman as husband and wife ... Any practice that potentially threatens the integrity of the family should not be seen as part of "freedom of choice.",281

Arguably, the IPHRC shows some begrudging willingness to recognize certain non-traditional family arrangements that break from its "ideal family consist[ing] of husband and wife." 282 For example, it acknowledges that a "single-parent family, especially woman-headed family" might be accommodated (though not legitimated) "as the consequence of divorce and other factors." ${ }^{283}$ The Commission outright rejects, however, the possibility that a family could be made up of two men or women who love each other, or that such a familial unit could be entitled to the same protection owed by the state to "a long-term consensual relationship between a man and a woman who are bound by the reciprocal rights and responsibilities enshrined in Islamic teachings." ${ }^{284}$

While the IPHRC wrapped up its internal deliberations over what family is - and what it is not - the OIC continued to take measures at the UN to protect the organization's vision of family. Most notably as part of this effort, the OIC pushed two contentious resolutions on "Protection of the Family" through the UN Human Rights Council

${ }^{279}$ OIC Independent Permanent Human Rights Commission (IPHRC) Concludes its 7th Regular Session in Jeddah, supra note 260 ("Future plans and projects that the Commission intends to deliberate upon [include] strengthening research and writing reports / position papers on the. . issue of sexual orientation.").

${ }^{280}$ IPHRC Thematic Debate on "Protection of Family Values", supra note 229. Saied Reza Ameli reaffirms this view on Islam's good society: "Islamic notions of an overriding accountability to Allah can sometimes clash with Western-secular notions of an overriding priority to uphold civil rights. For instance, liberal laws regarding homosexual practices or the consumption of alcohol cause difficulties for the devout Muslim, as they are seen to violate concepts of the good society and thus offend the Lord." Saied Reza Ameli, The Organisation of the Islamic Conference: Accountability and Civil Society, in Building Global Democracy? Civil SocieTy AND Accountable Global Governance 157 (Jan Aart Scholte, ed., Cambridge University Press, 2011).

${ }^{281}$ IPHRC Thematic Debate, on "Protection of Family Values", supra note 229.

${ }^{282} I d$.

${ }^{283}$ Id. ("Islam also provides guidance to protect this kind of family through different mechanisms such as inheritance, donation as well as the extended familial support system from the community and the government.").

${ }^{284} I d$. 
(HRC). ${ }^{285}$ The first resolution, passed in 2014 with all fourteen OIC states on the HRC voting in favor, ${ }^{286}$ was procedural in nature. It called for holding a panel discussion on protection of the family as well as preparing a report on that discussion. ${ }^{287}$ At the time, states opposed to the resolution expressed concern over its substance because it "did not refer to family diversity and the individual rights of family members." 288

The following year, shortly after conclusion of the IPHRC's 7th session, Egypt introduced a second "Protection of the Family" draft resolution co-sponsored by eighty-five UN member states including the African Group, the Arab Group, and fifty-five countries from the OIC. ${ }^{289}$ In the Egyptian ambassador's words, the document represented a "comprehensive substantive omnibus draft resolution on protection of the family ... building on ... 2014's procedural resolution." ${ }^{290}$ It also represented a significant push to entrench a narrow view of what constitutes family and on that basis establish which families merit protection of the state. For example, in urging States "to provide the family ... with effective protection and assistance" ${ }^{291}$ in the face of "increasing vulnerabilities," 292 the resolution recognizes only "singleheaded households, child-headed households and intergenerational households" as being "particularly vulnerable to poverty and social exclusion." 293

To more fully capture the resolution's effort to protect selective forms of family only, consider that it excludes from recognition "for example ... families comprising [LGBTI] persons; extended families; self-created and self-defined families; families without children; families of divorced persons... and non-traditional families resulting from

${ }^{285}$ Human Rights Council Res. 26/11, UN Doc. A/HRC/RES/26/11 (Jul. 16, 2014); see also Human Rights Council Res. 29/22, UN Doc. A/HRC/RES/29/22 (Jul. 22, 2015).

${ }^{286}$ Twenty-six states voted in favor, fourteen voted against, and six abstained.

${ }^{287}$ Human Rights Council Res. 26/11, supra note 285, at IIII 1, 2.

${ }^{288}$ OHCHR, Summary of the Human Rights Council Panel Discussion on the Protection of the Family, U.N. Doc. A/HRC/28/40, II 23 (2014).

${ }^{289}$ Amr Ramadan, Permanent Representative of Egypt to the UN, Introduction of Draft Resolution L.25 "Protection of the Family", Jul. 2, 2015, at II 1. (Albania was the only OIC state to vote against the resolution. All members of the Arab Group are OIC member states and OIC states make up 50 percent of the African Group. Palestine had no vote).

${ }^{290}$ Id. at $\mathbb{\text { II } 3}$.

${ }^{291}$ Human Rights Council Res. 29/22, supra note 285, at II 20.

${ }^{292}$ Id. at $\mathrm{I}[8$.

${ }^{293} I d$. at II 23. 
interreligious, intercommunity or inter-caste marriages." ${ }^{294}$ The challenge this narrow approach poses to the international human rights regime was evident to other members of the HRC. While acknowledging that families can make a valuable contribution to strengthening society, the EU states explained that they would vote against the resolution in the HRC because it "fails to recognize a basic and undeniable matter of fact-that in different cultural, political and social systems, various forms of the family exist. The recognition of the diversity of family forms is an essential element that this text lacks. ${ }^{295}$

In addition to recognizing only certain favored family units under IHRL, the HRC's contentious 2015 Resolution 29/22 on "Protection of the Family" also sought to link "policies and measures to protect the family" to the protection and promotion of the human rights of its members. ${ }^{296}$ Much like the OIC's effort to place protection for religion ahead of individual rights protection, ${ }^{297}$ the 2015 resolution purports to protect a narrow, OIC-friendly definition of family ahead of protection for actual individual rights holders, who may be the victim of human rights abuses generated in the context of family. The problem with such a formulation is that it enables states to pursue policies that either discount or altogether trump individual human rights in the name of protecting their favored family unit. For example, consider the IPHRC's rationalization for having women's rights take a backseat for the good of the family: "Islam has emphasized women's empowerment in raising a strong and integrated family through harmonious partnership with other family members, which is not at the cost of some one's disempowerment but for the overall betterment and sustainable development of all societies." 298

Resolution 29/22 also required the OHCHR to prepare a report on state obligations to protect the family. ${ }^{299}$ The substance of this report,

\footnotetext{
${ }^{294}$ U.N. Doc. A/HRC/29/40, supra note 205, at 923 . The Working Group concluded that "Although several international forums recognize family diversity, including "in different cultural, political and social systems", many of the aforementioned non-traditional forms of family are not recognized by all States." Id. at $\mathbb{I}[24$

${ }^{295}$ European Union, Explanation of Vote, UN Human Rights Council 29th session-Item 3: A/HRC/29/L.25.

${ }^{296}$ Human Rights Council Res. 29/22, supra note 285, at II 17.

${ }^{297}$ Blitt, supra note 15 .

${ }^{298}$ IPHRC $9^{\text {th }}$ Session Outcome Document, supra note 224 (emphasis added).

${ }^{299}$ Human Rights Council Res. 29/22, supra note 285, at II 29.
} 
released in 2016, is likely to engender strong OIC opposition. ${ }^{300}$ Arguably, its chief finding refutes the application of any narrow, "traditional" definition for family in the international context. According to the Office of the High Commissioner, the international community must:

$[\mathrm{R}]$ ecognize the diverse and changing forms of the family institution, in accordance with the different social, cultural and economic characteristics of every society; the promotion of equality between men and women; and the effective protection and promotion of the rights of women, children, persons with disabilities, older persons and all family members, without distinction. Moreover, ensuring universal access to sexual and reproductive health services, including family planning, should be an integral part of development efforts. ${ }^{301}$

Ultimately, the report observes that while states may "retain some leeway in defining the concept of family in national legislation, taking into consideration the various legal systems, religions, customs or traditions within their society," international law establishes "at least two minimum conditions for the recognition and protection of families at the national level." ${ }^{302}$ These conditions are "respect for the principle of equality and non-discrimination ... [and] the effective guarantee of the best interest of the child." ${ }^{303}$ Alongside these minimum requirements, international treaty bodies have elaborated supplemental state obligations, such as the need to protect specific forms of the familyincluding same-sex couples and de facto unions-"in view of the

${ }^{300}$ For a baseline, consider the reaction of the Center for Family \& Human Rights (C-Fam), a selfdescribed "pro-family" NGO, to the OHCHR report. The organization criticized the report for its "progressive, and aggressive, attempt to expand the meaning of family in international law and policy to include same-sex relationships." Stefano Gennarini, UN Report: "There Is No Definition of the Family," CENTER FOR FAMily \& HumAn Rights (C-Fam), (Jan. 29, 2016), https://c-fam.org/friday_fax/un-report-no-definition-family/. C-Fam previously labeled HRC Resolution 29/22 a "big win" and "monumental development for the pro-family movement." Rebecca Oas, Big Win for Traditional Family at UN Human Rights Council, CENTER FOR FAMILY \& HUMAN RIGHTS (Jul. 9, 2015), https://c-fam.org/friday_fax/big-win-for-traditionalfamily-at-un-human-rights-council/. C-Fam is an example of the type of NGO IPHRC refers to when it recommends "undertaking advocacy activities at relevant forums, including working with pro-family NGOs for holding conferences and seminars with the view to promoting and advancing family values." IPHRC Thematic Debate on "Protection of Family Values", supra note 229.

${ }^{301}$ OHCHR, Rep. Protection of the Family, II 77, U.N. Doc. A/HRC/31/37 (May 2, 2016).

${ }^{302} I d$. at $\mathbb{\text { II } 2 6 .}$

${ }^{303}$ For example, the UNCRC Committee "has called upon States to protect children from discrimination based on their own or their parents' or legal guardian's sexual orientation or gender identity." Id. The UNCRC prohibits all forms of abuse of children, including "based on their gender, sexual orientation or disability" Id. at IIII 42, 44. 
vulnerability of their members in relation to the enjoyment of human rights." ${ }^{304}$ In light of these findings, the report concludes that implementation of protection measures for family "should be guided by basic human rights principles, including equality and non-discrimination, and by respect for the rights of individual family members, notably those who might find themselves in a situation of vulnerability." 305

The OHCHR report reflects precisely the kind of balanced, inclusive, and individual rights-respecting policy for family protection that the OIC, in demanding that religious and traditional norms be respected above all, is attempting to short-circuit. So antithetical to international human rights norms is the OIC's campaign surrounding traditional family that - despite securing majority backing of the HRCthe UN Working Group on Discrimination Against Women bluntly concluded that the effort "threaten[s] to undermine international achievements in the field of human rights in the name of cultural and religious diversity." ${ }^{306}$

${ }^{304} I d$. at II 27. While states may not be required to allow same-sex couples to marry, "the obligation to protect individuals from discrimination on the basis of sexual orientation extends to ensuring that unmarried same-sex couples are treated in the same way and entitled to the same benefits as unmarried opposite-sex couples." Human Rights Council, Rep. of the OHCHR, Discriminatory Laws and Practices and Acts of Violence Against Individuals Based on Their Sexual Orientation and Gender Identity, II 68, UN Doc. A/HRC/19/41 (Nov. 17, 2011). Likewise, the UN Working Group on Discrimination Against Women has concluded "that the understanding and legal definition of the family in national legislation should be extended to recognize different forms of family", including "recognition of same-sex couples, for both women and men." UN Doc. A/HRC/29/40, supra note 205, at II 25.

${ }^{305} \mathrm{UN}$ Doc. A/HRC/31/37, supra note 301, at If 50.

${ }^{306}$ U.N. Doc. A/HRC/29/40, supra note 205, at II 19. For its part, the OIC regretted the Working Group's "attempts to redefine the universally established notion of family which is firmly rooted in International Human Rights Law. We believe that it is beyond the mandate of the Working Group to criticize [sic] resolution on family which was the outcome of inter-governmental negotiations and was adopted by Human Rights Council." Statement by Pakistan on Behalf of OIC During the Interactive Dialogue with the Special Rapporteur on Extrajudicial, Summary or Arbitrary Executions and Working Group on the Issue of Discrimination against Women in Law and in Practice, $29^{\text {th }}$ Session of Human Rights Council, June 19, 2015. The Working Group also was highly critical of HRC Resolution $16 / 3$ on promoting human rights and fundamental freedoms through a better understanding of traditional values of humankind. This contentious resolution can be traced back to 2009. At the time, it faced stiff opposition by the EU and others who argued incorporating the "concept of traditional values. . .could render human rights more vulnerable... [and] could be used to weaken human rights, as enshrined in international instruments." Press Release, Human Rights Council Adopts Six Resolutions and One Decision On Discrimination Against Women and Freedom of Expression, Among Others, (Oct. 2, 2009), http://reliefweb.int/report/myanmar/human-rights-council-adopts-six-resolutions-and-onedecision-discrimination-against. For example, the government of Iran "has actively sought to justify paternalism and gender-inequality under the guise of traditional values and cultural relativism." Letter from Women's Rights Activists to Members of the United Nation's Economic and Social Council (Apr. 28, 2010), http://www.unpo.org/content/view/11047/89/ (Over 200 


\section{CONCLUSION}

This article has sketched the OIC's effort to reinvigorate its international relevancy and deepen the nature of its engagement on the international level, particularly as it relates to the substance of IHRL. Underlying this initiative, the OIC has endorsed the universality of human rights while continuing to emphasize its own distinctly Islamic vision. In essence, the organization has taken the position that any purported rights it deems incompatible with Shari'ah necessarily fall outside of the "normal scope" of rights and thus amount to non-universal and non-obligatory norms. Further, where international bodies may insist on universality or when the preponderance of evidence validates such a standpoint, the OIC maintains that Shari'ah requires IHRL to yield to its norms.

As demonstrated above in the contexts of women's rights and family, the OIC's framing of equality and nondiscrimination-basic principles upon which the IHRL framework is built-is subject to the organization's invocation of vague Shari'ah norms. Where the OIC is confronted with claimed rights that indicate a conflict these rights are either characterized as non-universal, rendering them non-obligatory, or alternatively, they are flatly rejected based on incompatibility with Shari'ah. As will be confirmed in a forthcoming article that builds on the arguments raised here, the pattern is similarly evident in the context of SOGI rights.

The nature of the OIC's engagement with IHRL also helps to explain the organization's consistent need to mischaracterize the substance of the VDPA. Typically, this mischaracterization is manifested through an overemphasis on the declaration's constrained reference to religious particularities, or by ignoring the document's recognition of a prevailing duty on states to promote and protect all human rights. As Professor Bassam Tibi has observed:

[C]ultural pluralism cannot be extended so far as to become tantamount to cultural relativism. Thus to consider practices related to the violation of human rights. . as being an expression of a different culture cannot be tolerated. The pluralism of cultures is a

Iranian human rights activists and seven women's rights organizations endorsed the letter.); see also Robert C. Blitt, Russia's 'Orthodox' Foreign Policy: The Growing Influence of the Russian Orthodox Church in Shaping Russia's Policies Abroad, 33 U. PA. J. INT'L L. 363, 442-451 (2011) (discussing Russia's role in advancing the original "traditional values" resolution and its impact at the UN). 
supposition which refers to means but not to ends. In particular with regard to human rights there can be no compromise as far as these ends are concerned. . . cultural pluralism in the realm of human rights cannot mean more than a cultural indigenisation of basic individual human rights in local cultures. ${ }^{307}$

Deprived of the VDPA's international imprimatur, the OIC's Shari'ahfirst resolve is reduced to advocacy of a relativistic understanding of human rights that directly conflicts with the organization's endorsement of universality. The credibility dilemma inherent with maintaining such a position on the international level is apparent to the OIC. As such, it has recently taken to blaming states supportive of IHRL for forcing the organization into this relativistic corner:

\begin{abstract}
We believe that we should not attempt to pursue as universal values things that are not universally acceptable. Also, we should not use universality to shield self proclaimed rights. The attempt to pursue under the garb of universality, concepts that also force the other side to use the argument of cultural relativism or religion, is not acceptable. $^{308}$
\end{abstract}

To avoid the appearance of isolation and relativism on the issue of equality and nondiscrimination, the OIC has enlisted the assistance of the IPRHC. As demonstrated above, this newly minted principal OIC organ is premised on a defective mandate, lacks independence, and has willingly embraced the role of norm validator for the organization, but is nevertheless depicted as an independent and expert human rights mechanism. This chimera has created - at least on the surface-an additional veneer of legitimacy for the OIC's efforts to constrain the scope and application of IHRL. Indeed, the OIC is quick to invoke as authorative the IPHRC's "clear pronouncements" ${ }^{309}$ on a range of human rights issues, despite the commission's failure to undertake any meaningful and independent enquiry into the substance of rights or the content of Shari'ah.

Based on these conclusions, it should be apparent that the OIC's international engagement efforts in the context of equality and nondiscrimination are deeply problematic. At the same time, the OIC is

\footnotetext{
${ }^{307}$ Bassam Tibi, Human Rights in Islamic Civilisation and in the West: International Morality as a Cross-Cultural Foundation, in THE WeST AND Islam: TOWARDS A DiALOGUe 59-60 (Zeynep Durukal Abushusayn \& Muhammad Isa Waley eds. 1999).

${ }^{308}$ Statement by Pakistan on behalf of OIC, $31^{\text {st }}$ HRC Session ID with HC under Item 2, (Mar. 10, 2016) (Interactive dialogue with OHCHR High Commissioner) (emphasis added). ${ }^{309}$ Id.
} 
but one voice for Islam. There is a strong claim to be made that the organization even distorts the true essence of Islam and the actual requirements of Shari'ah. ${ }^{310}$ Nevertheless, the OIC, as the proclaimed "collective voice of the Muslim world," still represents fifty-seven member states at the UN and flexes an unmatched level of access and influence, including a sizable and constant presence on the HRC. ${ }^{311}$ This influence continues to dominate the narrative on Islam far beyond the voice of any academic, activist, or NGO, and colors not only the debate around rights but their substance as well. Considering this reality, and the need for a concerted response, the article closes with several general recommendations directed at concerned advocates and policymakers alike. First, support more defined and rigorous criteria for cooperation and interaction with the UN OHCHR. Further to this end, given its established track record, cease cooperation with the IPHRC at the UN and on the bilateral level until it clearly adopts and endorses (rather than builds conflict with) existing IHRL norms, including treaty body general comments. Second, fund organizations and initiatives developing alternate interpretations of Islam that more fully comport with IHRL, that report on rights violations in OIC states, and that advocate and educate for a fuller understanding of equality and nondiscrimination in those states. Third, identify OIC members that either abstain or vote against harmful IHRL-related initiatives at the UN and reward them through trade and other incentives. Further, work through these states to expand OIC moderation from the inside and to deepen the "alternate" understanding of Islam being developed by Muslim jurists, scholars, and activists. Fourth, more forcefully and consistently call attention to the incompatibility of certain OIC positions with IHRL. The practice of naming and shaming should be made more systematic and more widely disseminated. Last, further empower moderate voices through greater international exposure, for example, by identifying witnesses and experts to testify at the UN and other international fora in the context of equality

310 There is a wealth of analysis on this issue. See e.g., U.N. Human Rights Council, supra note 51; Abdullah Ahmed An-Na'im, Islam and the SeCular State: Negotiating tHe Future OF SHARI'A (Harvard University Press, 2008); see also MOHAMMAD HASHIM KAMALI, FrEEDOM OF EXPRESSION IN ISLAM (Berita Publishing SDN.BHD., 1994); see also Javaid Rehman \& Eleni Polymenopoulou, Is Green a Part of the Rainbow? Sharia, Homosexuality, and LGBT Rights in the Muslim World, 37 FORDHAM INT'L L.J. 1 (2013).

311 At the time of writing, twelve OIC states held membership in the HRC, representing one quarter of the Council's total membership of forty-seven. See OHCHR, Current Membership of the Human Rights Council, 1 January - 31 December 2017, http://www.ohchr.org/EN/HRBodies/HRC/Pages/CurrentMembers.aspx. 
and nondiscrimination. This effort should include Muslim women, LGBTI Muslims, representatives of religious minorities in OIC states, Islamic scholars, and others. 